\title{
Altered Sleep Homeostasis after Restraint Stress in 5-HTT Knock-Out Male Mice: A Role for Hypocretins
}

\author{
Adeline Rachalski, ${ }^{1,2}$ Chloé Alexandre, ${ }^{1,2}$ Jean-François Bernard, ${ }^{1,2}$ Françoise Saurini, ${ }^{1,2}$ Klaus-Peter Lesch, ${ }^{3}$ \\ Michel Hamon, ${ }^{1,2}$ Joëlle Adrien, ${ }^{1,2}$ and Véronique Fabre ${ }^{1,2}$ \\ ${ }^{1}$ Université Pierre et Marie Curie-Paris 6, Faculté de Médecine Pierre et Marie Curie, Site Pitié-Salpêtrière, Institut Fédératif de Recherche 70 des \\ Neurosciences, Unité Mixte de Recherche S677, F-75013 Paris, France, ${ }^{2}$ Inserm, Unité 677, F-75013 Paris, France, and ${ }^{3}$ Department of Psychiatry, \\ University of Würzburg, 97080 Würzburg, Germany
}

Restraint stress produces changes in the sleep pattern that are mainly characterized by a delayed increase in rapid eye movement sleep (REMS) amounts. Because the serotonin (5-HT) and the hypocretin (hcrt) systems that regulate REMS are interconnected, we used mutant mice deficient in the 5-HT transporter $\left(5-\mathrm{HTT}^{-/-}\right)$to examine the role of 5-HT and hcrt neurotransmissions in the sleep response to stress.

In contrast to wild-type mice, restraint stress did not induce a delayed increase in REMS amounts in $5-H T T^{-/-}$mice, indicating impaired sleep homeostasis in mutants. However, pharmacological blockade of the hcrt type 1 receptor (hcrt-R1) before restraint stress restored the REMS increase in 5-HTT ${ }^{-/}$mice. In line with this finding, 5-HTT ${ }^{-/}$mutants displayed after restraint stress higher long-lasting activation of hypothalamic preprohcrt neurons than wild-type mice and elevated levels of the hort-1 peptide and the hort-R1 mRNA in the anterior raphe area. Thus, hypocretinergic neurotransmission was enhanced by stress in $5-H T T^{-1-}$ mice. Furthermore, in 5-HTT ${ }^{-/-}$but not wild-type mice, hypothalamic levels of the 5-HT metabolite 5-hydroxyindole acetic acid significantly increased after restraint stress, indicating a marked enhancement of serotonergic neurotransmission in mutants.

Altogether, our data show that increased serotonergic -and in turn hypocretinergic- neurotransmissions exert an inhibitory influence on stress-induced delayed REMS. We propose that the direct interactions between hcrt neurons in the hypothalamus and 5-HT neurons in the anterior raphe nuclei account, at least in part, for the adaptive sleep-wakefulness regulations triggered by acute stress.

\section{Introduction}

Stress or aversive life events are known to alter sleep and wakefulness. Such stress-induced changes in the sleep-wakefulness patterns have been proposed to be part of the process that enables an organism to adapt to emotional inputs (Van Reeth et al., 2000). In rodents, restraint stress (RS) has been found to produce a delayed increase in rapid eye movement sleep (REMS) that may last for up to $10 \mathrm{~h}$ (Rampin et al., 1991) and depends on serotonergic mechanisms. Thus, in rats, stimulation of the dorsal raphe nucleus (DR), which increases 5-HT release in the hypothalamus, is sufficient to induce a delayed increase in REMS (Houdouin et al., 1991a,b). Conversely, this phenomenon is abolished in transgenic mouse models with permanent impairment of 5-HT neurotransmission (Boutrel et al., 2002; Adrien et al., 2004; Popa et al., 2008).

\footnotetext{
Received July 2, 2009; revised 0ct. 26, 2009; accepted 0ct. 28, 2009.

This research was supported by INSERM, Université Pierre et Marie Curie, and European Community (Program Newmood Contract LSHM-CT-2003-503474, FWP6). A.R. was a recipient of grants from Société Française de Pharmacologie et de Thérapeutique and Agence Nationale de la Recherche (ANR-Serotonin 2C Receptor mRNA Editing Grant R06319DS) during performance of this work. We are especially grateful to Maxette Melfort for genotyping and to Marie-Hélène Thiébot and Clément Léna for expert help in statistics.

Correspondence should be addressed to Véronique Fabre, Centre de Recherche de l'Institut du Cerveau et de la Moelle Epinière, INSERM, Unité Mixte de Recherche S975, Centre National de la Recherche Scientifique Unité Mixte de Recherche 7225, Université Pierre et Marie Curie, Site Pitié-Salpêtrière, 91, Boulevard de l'Hôpital, 75634 Paris Cedex 13, France. E-mail: veronique.fabre@upmc.fr.

D01:10.1523/JNEUROSCI.3138-09.2009

Copyright $\odot 2009$ Society for Neuroscience 0270-6474/09/2915575-11\$15.00/0
}

Mutant mice that do not express the serotonin transporter $\left(5-\mathrm{HTT}^{-/-}\right)$exhibit a marked increase in extracellular 5-HT levels (Fabre et al., 2000; Mathews et al., 2004), which, in turn, triggers adaptive changes in 5-HT receptor expression and/or function (for review, see Murphy et al., 2008). In addition, 5-HTT ${ }^{-1-}$ mice show exaggerated hypothalamic-pituitary-adrenal (HPA) responses that may correlate with an increased reactivity to stress and anxiety-like behaviors (Hariri and Holmes, 2006). Therefore, $5-H T T^{-/-}$mutants are a relevant model to explore further the influence of stress on sleep-wakefulness patterns and to elucidate underlying neurobiological mechanisms.

Hypocretins (hcrt)/orexins are two neuroexcitatory peptides, hypocretin-1 (orexin-A) and hypocretin-2 (orexin-B), first isolated from the rat hypothalamus, which derive from a single precursor, the preprohcrt (de Lecea et al., 1998; Sakurai et al., 1998). Both hcrt and 5-HT play essential roles in the control of sleep and wakefulness, notably through an inhibitory influence on REMS generation (Pace-Schott and Hobson, 2002; Lu et al., 2006). Indeed, these peptides and the indolamine exhibit strong interconnections: (1) hypocretin neurons send projections to some raphe nuclei, and, in turn, they receive 5-HT inputs (Peyron et al., 1998; H. S. Lee et al., 2005; Sakurai et al., 2005; Wang et al., 2005; Yoshida et al., 2006), and (2) 5-HT hyperpolarizes hypocretin neurons by activating $5-\mathrm{HT}_{1 \mathrm{~A}}$ receptors (Collin et al., 2002; Li et al., 2002; Muraki et al., 2004), whereas hypocretins excite DR 5-HT neurons by acting at hort-R1 and hort-R2 receptor subtypes 


\section{$5-\mathrm{HTT}+/+$}
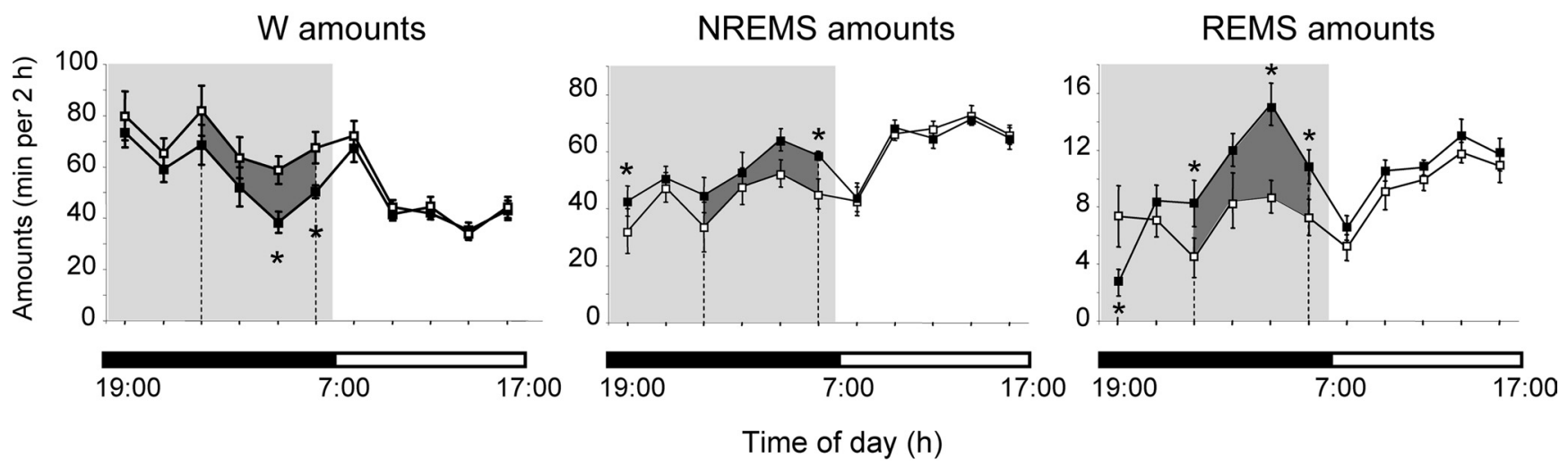

\section{5-HTT-/-}
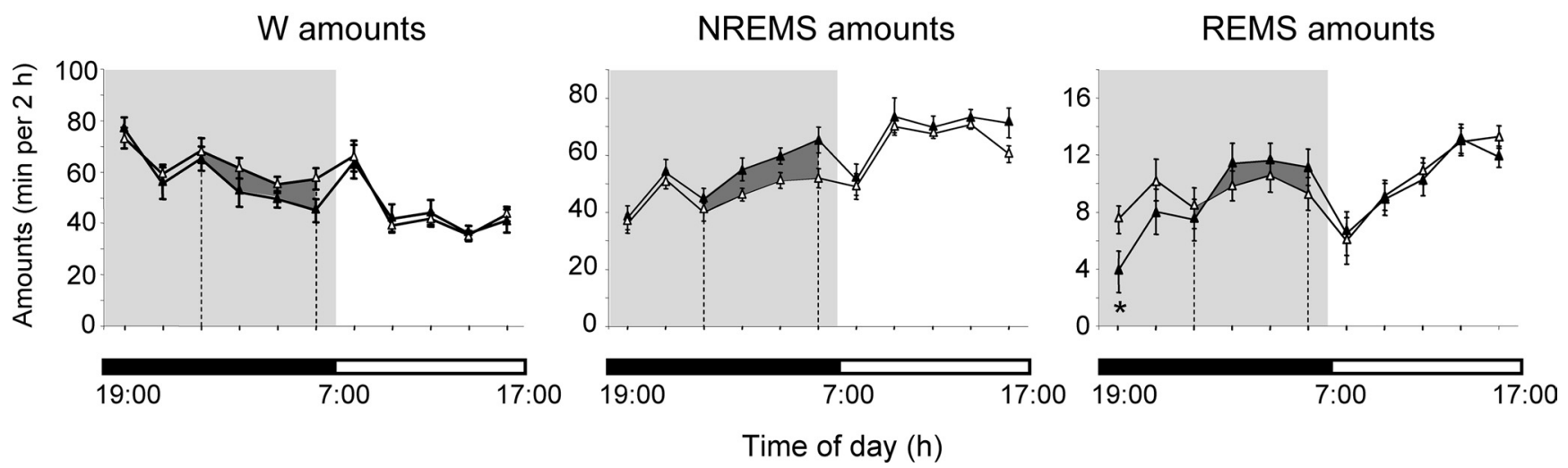

Figure 1. Effects of restraint stress on sleep-wakefulness patterns in 5-HTT ${ }^{+/+}$and $5-H T T^{-/-}$mice. Sleep-wakefulness states across the light/dark cycle under control conditions (open

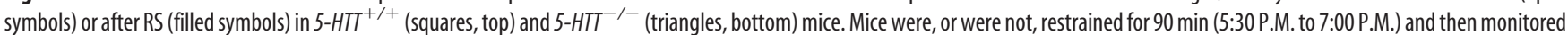
for sleep and wakefulness (from 7:00 P.M. on day 1 to 5:00 P.M. on day 2; abscissa). Amounts of vigilance states, expressed as minutes per $2 \mathrm{~h}$, are the mean \pm SEM of eight animals in each group. The gray area corresponds to the difference between control and RS conditions. ${ }^{*} p<0.05$, significantly different from the control conditions; paired Student's $t$ test after ANOVA.

(Brown et al., 2001, 2002; Marcus et al., 2001; Liu et al., 2002; Soffin et al., 2004; Takahashi et al., 2005; Wang et al., 2005; Tao et al., 2006).

On this basis, our aim was to specify the role of 5-HT and hypocretin in stress-altered sleep in an animal model with well characterized alterations in 5-HT neurotransmission, 5-HTT ${ }^{-/-}$ mutants versus paired wild-type $\left(5-H T T^{+/+}\right)$mice. We notably investigated the physiological role of hypocretin neurons in stress-induced sleep modifications by assessing the effects of hcrt-R1 blockade during stress on subsequent sleep in $5-H T T^{-1-}$ versus $5-H T T^{+/+}$mice. Finally, we also examined the impact of 5-HTT deficiency on serotonergic and hypocretinergic neurotransmissions under control conditions and after RS in both mutants and wild-type mice.

\section{Materials and Methods}

\section{Animals}

Founder 5-HTT knock-out mice were obtained originally from the colony of author K.P.L. (Bengel et al., 1998) and were successively backcrossed (F7) with the Swiss albino CD-1 strain (Charles River). Males of each genotype were born from either heterozygous $(n=82)$ or homozygous $(n=114)$ breeding. Genotyping was performed by PCR (Bengel et al., 1998). Animals were housed in a temperature-controlled room (23 \pm $1^{\circ} \mathrm{C}$ ) under $12 \mathrm{~h} \mathrm{light/dark} \mathrm{cycle} \mathrm{(lights} \mathrm{on} \mathrm{at} \mathrm{7:00} \mathrm{A.M.),} \mathrm{with} \mathrm{food} \mathrm{and}$ water available ad libitum. Animal care and experiments were conducted in accordance with the institutional guidelines, which are in compliance with national and international laws and policies (council directive 87848, October 19, 1987, Ministère de l'Agriculture et de la Forêt, Service vétérinaire de la santé et de la protection animale; permissions 75-116 to M.H. and 75-125 to J.A.).

\section{Experimental design}

To gain insight into the physiological involvement of hypocretin neurons in stress-altered sleep in 5-HTT ${ }^{-/-}$mutants versus $5-H T T^{+/+}$mice, we performed two sets of experiments.

\section{Experiment 1}

RS consequences on sleep-wakefulness patterns were analyzed in 5-HTT $T^{-/-}$and 5-HTT $T^{+/+}$mice. To this aim, animals were restrained (RS groups) or not (control groups) for $90 \mathrm{~min}$ and then monitored for sleep and wakefulness. In addition, to characterize the role of hypocretin neurons in stress-altered sleep, we evaluated the consequences of hcrt-R1 blockade before RS on sleep.

Sleep and wakefulness analysis

Surgery. At 2-4 months of age, under deep sodium pentobarbital anesthesia $(80 \mathrm{mg} / \mathrm{kg}$, i.p.), animals were implanted with electrodes (made of enameled nichrome wire; diameter, $150 \mu \mathrm{m}$ ) for polygraphic sleep monitoring (Boutrel et al., 2002). Briefly, two electroencephalogram (EEG) electrodes were positioned onto the dura through holes made into the skull ( $2 \mathrm{~mm}$ lateral and $2 \mathrm{~mm}$ caudal to the bregma suture; $1 \mathrm{~mm}$ caudal to the lambda at midline), two electrooculogram electrodes were placed subcutaneously on each side of the orbit, and two electromyogram electrodes were inserted into the neck muscles. All electrodes were anchored to the skull with Superbond (GACD) and acrylic cement and were soldered to a miniconnector also embedded in cement. The animals were transferred to individual recording cages $(20 \times 20 \times 30 \mathrm{~cm})$ and were 
A

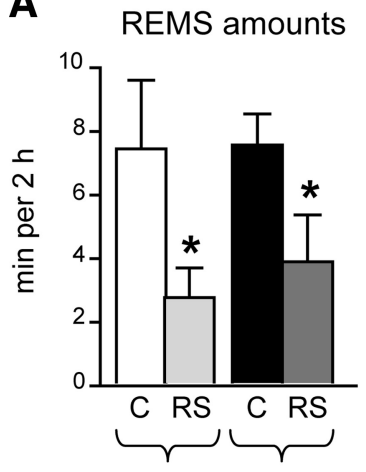

$5-\mathrm{HTT}+/+5-\mathrm{HTT}-/-$

\section{B REMS amounts}

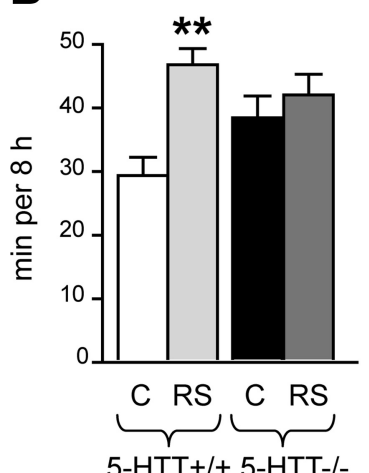

$5-\mathrm{HTT}+/+5-\mathrm{HTT}-/-$

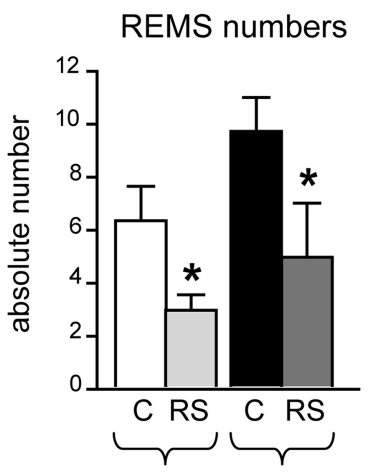

$5-\mathrm{HTT}+/+5-\mathrm{HTT}-/-$

REMS numbers

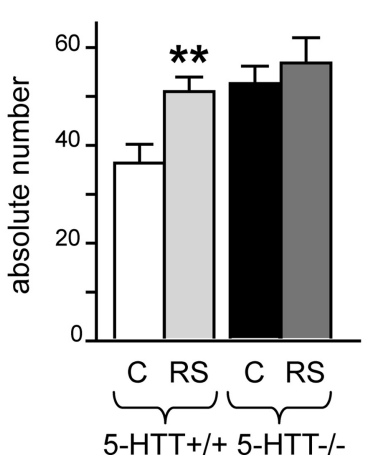

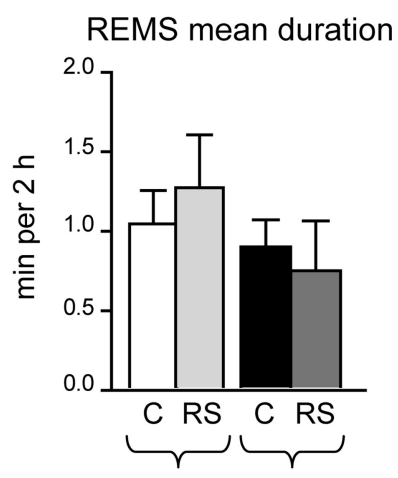

$5-\mathrm{HTT}+/+5-\mathrm{HTT}-/-$

REMS mean duration

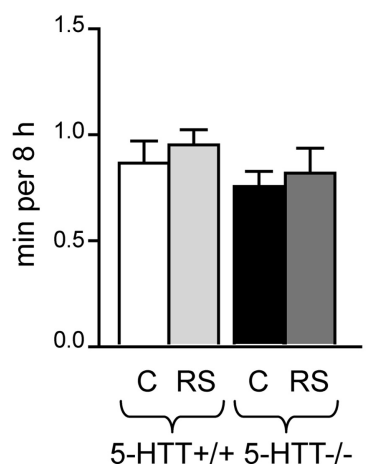

Figure 2. Restraint stress alters REMS pattern in $5-\mathrm{HTT}^{+/+}$and $5-\mathrm{HTT}^{-/-}$mice. Mice were, or were not, restrained for $90 \mathrm{~min}$ (5:30 P.M. to 7:00 P.M.) and then monitored for sleep and wakefulness starting at 7:00 P.M. A, REMS amounts, absolute number, and mean duration of REMS episodes for the first $2 \mathrm{~h}$ (7:00 P.M. to 9:00 P.M. period) after the $90 \mathrm{~min}$ control (C) or RS session in 5-HTT ${ }^{+/+}$and 5-HTT ${ }^{-1}$ mice. B, REMS characteristics for the following $8 \mathrm{~h}$ period (11:00 P.M. to 7:00 A.M.) in the same control (C) and $\mathrm{RS} 5-\mathrm{HTT}^{+/+}$and $5-\mathrm{HTT}^{-/-}$mice. Data are the mean \pm SEM of independent determinations in eight animals in each group. ${ }^{*} p<0.05,{ }^{* *} p<0.01$, significantly different from the control condition; paired Student's $t$ test after ANOVA.

allowed to recover for $10 \mathrm{~d}$ under standard conditions (see above). They were habituated to the recording cables for $2-3 \mathrm{~d}$ before recordings were started.

Recordings. The mice were connected to the recording system with a light-weight cable and a swivel allowing free movements in the cage. Animals were recorded by groups of four, usually two $5-H T T^{-/}$and two 5-HTT ${ }^{+/+}$mice. Spontaneous sleep-wakefulness patterns were first examined by recording mice for $24 \mathrm{~h}$ (baseline recordings).

Restraint stress. RS was performed by wrapping each mouse in a nyloncovered metal mesh during $90 \mathrm{~min}$ (5:30 P.M. to 7:00 P.M.), as described previously (Boutrel et al., 2002; Léna et al., 2004). At the end of RS session, mice were returned to their cage for sleep-wakefulness monitoring until 5:00 P.M. the next day. Matched control recordings were obtained the day before RS procedure, after disconnecting (5:30 P.M.) and connecting again (7:00 P.M.) the recording cables. Sleep-wakefulness was monitored for $22 \mathrm{~h}$ thereafter, as after the RS session.

Pharmacological treatment. To determine the consequences of hcrt-R1 blockade on sleep-wakefulness patterns in $5-H T T^{-1-}$ and $5-H T T^{+/+}$ mice, we administered the hcrt-R1 antagonist SB-334867 [1-(2-methylbenzoxazol-6-yl)-3-[1,5]naphthydrin-4-yl urea $\mathrm{HCl}]$ (Tocris Bioscience) at 5:00 P.M. [30 mg/kg, i.p., dissolved in 10\% hydroxy-propyl- $\beta$ cyclodextrin (Kleptose; Roquette Frères) and 1\% dimethylsulfoxide]. The dose of $30 \mathrm{mg} / \mathrm{kg}$ SB-334867 was chosen because a higher dose (60 $\mathrm{mg} / \mathrm{kg})$, tested in a pilot study $(n=4)$, produced in half of the animals a nonspecific state close to sedation with immobility and slightly desynchronized EEG (data not shown). In addition, at the dose of $30 \mathrm{mg} / \mathrm{kg}$, SB-334867 was already shown to prevent hort-1-induced inhibition of REMS in rats (Smith et al., 2003). For baseline data, mice were injected intraperitoneally with the vehicle only. Other groups of mice received the antagonist or vehicle, before the RS or control procedure, and polygraphic recordings were collected as above.
Scoring and analysis. Polygraphic recordings were visually scored every $5 \mathrm{~s}$ epoch as wakefulness (W), non-REM sleep (NREMS), or REMS following classical criteria (Boutrel et al., 2002; Léna et al., 2004) using the Somnologica software (Medcare). NREMS latency was defined as time elapsed between the end of RS or control procedures and the first NREMS bout (lasting at least $15 \mathrm{~s}$ ). To assess the RS effect on REMS latency, we also determined the time interval between the beginning of the first NREMS bout and the occurrence of the first REMS bout (lasting at least $15 \mathrm{~s}$ ), after RS and control procedures. Total amount and the number and mean duration of episodes of each vigilance state were averaged over $2 \mathrm{~h}$ periods and over the 11:00 P.M. to 7:00 A.M. segment $(8 \mathrm{~h})$. Analyses were conducted using Matlab (MathWorks) routine (Léna et al., 2004).

\section{Experiment 2}

We determined the influence of RS on serotonergic and hypocretinergic neurotransmissions in mice of both genotypes. To this aim, 5-HTT ${ }^{-/-}$and $5-H T T^{+/+}$mice were restrained (RS groups) or not (control groups) for $90 \mathrm{~min}$. Serotonergic neurotransmission was evaluated by measuring 5-HT and 5-hydroxyindole acetic acid (5-HIAA) tissue contents by HPLC. Hypocretinergic neurotransmission was evaluated by determination of (1) the number of active hypocretin neurons, characterized by double preprohypocretin (preprohcrt) and c-Fos immunolabeling, (2) hcrt-1 tissue contents by radioimmunoassay, and (3) hort-R1 and hort-R2 mRNA levels by real-time PCR.

\section{Restraint stress}

Mice were subjected to the same RS procedure as the one described above. At the end of the RS session, mice were immediately killed by decapitation or by deep anesthesia for perfusion. To evaluate the influence of RS on hypocretin neuron activation, another group of mice was returned to their home cage to be perfused $5 \mathrm{~h}$ later.

\section{Measurements of 5-HT and 5-HIAA}

Restrained and control mice of each genotype were decapitated, and their brains were rapidly removed in the cold $\left(0^{\circ} \mathrm{C}\right)$. The hypothalamus was dissected, weighed, and homogenized in 10 volumes $(\mathrm{v} / \mathrm{w})$ of $0.1 \mathrm{~N}$ $\mathrm{HClO}_{4}$ containing $0.05 \% \mathrm{Na}_{2} \mathrm{~S}_{2} \mathrm{O}_{5}$ and $0.05 \%$ disodium EDTA. Homogenates were centrifuged at $30,000 \times g$ for $15 \mathrm{~min}$ at $4^{\circ} \mathrm{C}$, and the supernatants were neutralized with $2 \mathrm{M} \mathrm{KH}_{2} \mathrm{PO}_{4} / \mathrm{K}_{2} \mathrm{HPO}_{4}$, $\mathrm{pH}$ 7.4, supplemented with ascorbate oxidase (final concentration, $10 \mu \mathrm{g} / \mathrm{ml}$; Boehringer Mannheim). After a second centrifugation as above to eliminate $\mathrm{KClO}_{4}$ precipitate, the clear supernatants were saved, and aliquots $(10-20 \mu \mathrm{l})$ were injected directly into a HPLC column $(25 \mathrm{~cm}, 0.46 \mathrm{~cm}$ outer diameter, $5 \mu \mathrm{m}$ particle size; Ultrasphere IP; Beckman Coulter) protected with a Brownlee precolumn $(3 \mathrm{~cm}, 5 \mu \mathrm{m})$. The mobile phase (at a flow rate of $1 \mathrm{ml} / \mathrm{min}$ ) consisted of $70 \mathrm{~mm} \mathrm{KH}_{2} \mathrm{PO}_{4}, 2 \mathrm{~mm}$ triethylamine, $0.1 \mathrm{~mm}$ disodium EDTA, $1.25 \mathrm{~mm}$ octane sulfonic acid, and $16 \%$ methanol, adjusted to $\mathrm{pH} 3.02$ with solid citric acid. Electrochemical detection (ESA 5011) with dual coulometric monitoring electrodes (+50 and $+350 \mathrm{mV}$ ) was coupled with a computing integrator (System-Gold; Beckman Coulter) for the quantitative determinations of 5-HT and 5-HIAA with reference to pure standards (Hamon et al., 1988).

\section{Functional neuroanatomy}

Preparation of brain sections. Animals of each phenotype were deeply anesthetized with sodium pentobarbital $(80 \mathrm{mg} / \mathrm{kg}$, i.p.) and perfused 


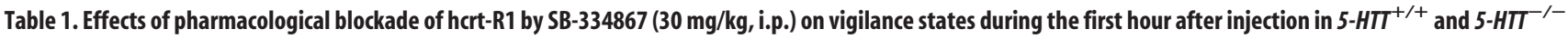
mice

\begin{tabular}{|c|c|c|c|c|c|c|}
\hline & \multicolumn{2}{|l|}{ Wake } & \multicolumn{2}{|l|}{ NREMS } & \multicolumn{2}{|l|}{ REMS } \\
\hline & $5-H T T^{+/+}$ & 5-HTT $T^{-1-}$ & $5-\mathrm{HTT}^{+/+}$ & 5-HTT ${ }^{-/-}$ & $5-H T^{+/+}$ & $5-\mathrm{HTT}^{-/-}$ \\
\hline \multicolumn{7}{|l|}{ Vehicle } \\
\hline Amounts (min) & $34.0 \pm 2.5$ & $32.5 \pm 2.3$ & $21.9 \pm 2.2$ & $22.5 \pm 1.9$ & $4.1 \pm 0.9$ & $5.0 \pm 0.8$ \\
\hline Episodes (absolute number) & $40.6 \pm 3.9$ & $29.9 \pm 2.4^{\#}$ & $39.9 \pm 3.9$ & $29.4 \pm 2.3^{\#}$ & $10.0 \pm 2.4$ & $6.9 \pm 1.7$ \\
\hline \multicolumn{7}{|l|}{ SB-334867 } \\
\hline Amounts (min) & $32.8 \pm 1.8$ & $36.0 \pm 1.1$ & $23.5 \pm 1.9$ & $21.2 \pm 1.2$ & $3.7 \pm 0.7$ & $2.7 \pm 0.6$ \\
\hline Episodes (absolute number) & $41.3 \pm 1.7$ & $29.0 \pm 1.4^{\# \# \#}$ & $40.9 \pm 1.6$ & $28.7 \pm 1.3^{\# \# \#}$ & $9.6 \pm 2.7$ & $6.4 \pm 1.1$ \\
\hline
\end{tabular}

Values are expressed as the mean \pm SEM of seven animals in each group. ${ }^{*} p<0.05,{ }^{\# \#} p<0.001,5-H T T^{-1-}$ mutants versus wild-type mice; Fisher's PLSD test after ANOVA.

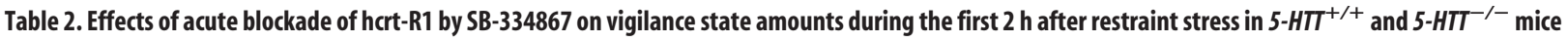

\begin{tabular}{|c|c|c|c|c|c|c|}
\hline & \multicolumn{2}{|l|}{ Wake (min) } & \multicolumn{2}{|l|}{ NREMS (min) } & \multicolumn{2}{|l|}{ REMS (min) } \\
\hline & $5-H T T^{+/+}$ & $5-H T T^{-1-}$ & $5-H T T^{+/+}$ & $5-H T T^{-1-}$ & $5-\mathrm{HTT}^{+/+}$ & $5-H T T^{-/-}$ \\
\hline Vehicle + control (day 1$)$ & $76.3 \pm 3.5$ & $73.9 \pm 5.4$ & $38.3 \pm 3.3$ & $39.6 \pm 5.1$ & $5.4 \pm 0.7$ & $6.5 \pm 0.6$ \\
\hline Vehicle + stress (day 2) & $74.8 \pm 4.7$ & $68.0 \pm 4.8$ & $42.3 \pm 4.8$ & $48.8 \pm 4.3$ & $2.9 \pm 0.4^{* *}$ & $3.2 \pm 1.0^{* * *}$ \\
\hline Vehicle + control (day 1) & $68.9 \pm 3.3$ & $64.9 \pm 5.4$ & $43.3 \pm 2.7$ & $45.6 \pm 4.7$ & $7.8 \pm 1.0$ & $9.5 \pm 1.5$ \\
\hline SB-334867 + stress (day 2) & $64.2 \pm 5.8$ & $68.6 \pm 2.8$ & $51.6 \pm 6.2$ & $47.6 \pm 2.8$ & $4.2 \pm 1.1^{*}$ & $3.9 \pm 0.6^{*}$ \\
\hline
\end{tabular}

See Figure $3 A$ for the experimental protocol. Values are expressed as the mean \pm SEM of eight to nine mice in each group. ${ }^{*} p<0.05,{ }^{* *} p<0.01$, and ${ }^{* * *} p<0.001$, restraint stress versus control condition; paired Student's $t$ test after ANOVA.

intracardially with $100 \mathrm{ml}$ of $4 \%$ paraformaldehyde (PFA) in PBS (50 mM $\mathrm{NaH}_{2} \mathrm{PO}_{4} / \mathrm{Na}_{2} \mathrm{HPO}_{4}$ and $154 \mathrm{~mm} \mathrm{NaCl}, \mathrm{pH}$ 7.4). Brains were removed, immersed for $12 \mathrm{~h}$ in the same fixative, and cryoprotected for $24 \mathrm{~h}$ in $30 \%$ sucrose in PBS. Brains were then quickly frozen in isopentane chilled at $-30^{\circ} \mathrm{C}$ with dry ice and stored at $-20^{\circ} \mathrm{C}$. The frozen brains were cut into three series of $30-\mu \mathrm{m}$-thick coronal sections at the level of the hypothalamic perifornical region using a cryostat (CM3050S; Leica). The collected sections were stored at $-20^{\circ} \mathrm{C}$ in cryoprotectant solution $(30 \%$ glycerol and 30\% ethylene glycol in PBS).

\section{Double immunohistochemistry}

Hypocretin/c-Fos. One series of sections was used to detect both c-Fos and preprohcrt in the hypothalamic perifornical region. For the first step (c-Fos immunostaining), sections were incubated overnight at $4^{\circ} \mathrm{C}$ with rabbit polyclonal anti-c-Fos antiserum [1:20,000, c-Fos (ab-5); Oncogene Science] in PBS containing 4\% bovine serum albumin (BSA) and $0.1 \%$ Triton X-100. After rinsing in PBS supplemented with $0.1 \%$ Triton $\mathrm{X}-100$, sections were incubated for $2 \mathrm{~h}$ with biotinylated anti-rabbit IgG (1:200 dilution with ABC Vectastain Elite kit; Vector Laboratories) in PBS containing 4\% BSA and $0.1 \%$ Triton X-100. Additional rinses were followed by incubation with avidin-biotin-horseradish peroxidase solution (ABC Vectastain Elite kit; Vector Laboratories) for $1 \mathrm{~h}$, and c-Fos immunoreactivity was visualized as a black reaction product after incubation of the sections in $0.05 \mathrm{M}$ Tris- $\mathrm{HCl}, \mathrm{pH} 7.6$, containing $0.04 \%$ (w/v) of 3,3'-diaminobenzidine (DAB) (Sigma) and $0.2 \%$ ammonium nickel sulfate (Sigma), supplemented with increasing concentrations of $\mathrm{H}_{2} \mathrm{O}_{2}$ (from 0.00015 to $0.0048 \%$ ). For the second step, sections were rinsed and incubated overnight with a rabbit anti-preprohcrt antiserum (1:200 dilution; Alpha Diagnostics). After rinses, sections were treated with $0.03 \%$ $\mathrm{H}_{2} \mathrm{O}_{2}$ in PBS to inactivate remaining peroxidase activity. The immunohistochemical procedure was then processed as described previously. For staining, sections were treated with $0.04 \%$ DAB in PBS, yielding a brown cytoplasmic product in preprohcrt-immunoreactive (IR) neurons. Stained sections were finally mounted on gelatin-coated slides, dehydrated, and coverslipped with Eukitt mounting medium (Kindler).

Cell counting. The resultant signals were quantified using the cell counting software Mercator Lite 3.0B (Explora Nova). Two examiners, blind to the experimental conditions, performed all the cell counts using a microscope at various magnifications $(2.5 \times$ to $40 \times)$, as needed. Double-labeled neurons were carefully analyzed at high magnification $(40 \times)$. All perifornical preprohcrt-IR and double-labeled neurons were counted on both sides of the brain in two different sections, $90 \mu \mathrm{m}$ apart, without considering the intensity of the staining. For each mouse, the number of labeled cells of each type was then averaged per section.

\section{Hcrt-1 tissue contents}

Peptide extraction. Restrained and control mice of each genotype were decapitated, and the anterior part of the raphe area (which contains 5-HT cell bodies of the median and dorsal raphe nuclei) was dissected out and frozen at $-80^{\circ} \mathrm{C}$ until use. For peptide extraction, frozen tissues were homogenized by sonication in $100 \mu$ of $0.1 \mathrm{~N} \mathrm{HCl}$ and boiled for $15 \mathrm{~min}$. After centrifugation $\left(30,000 \times \mathrm{g}, 15 \mathrm{~min}, 4^{\circ} \mathrm{C}\right)$, the supernatant was adjusted to $\mathrm{pH} 7.0$ with $1 \mathrm{~m}$ Tris base. The resulting precipitate was spun down by a second centrifugation at $30,000 \times g$ for $15 \mathrm{~min}$ at $4^{\circ} \mathrm{C}$. The clear extract was assayed for its hcrt- 1 content at 1:10 dilution, and residues were allotted to protein assays.

Hcrt-1 assay. Hcrt-1 contents were measured using a [ $\left.{ }^{125} \mathrm{I}\right]$ RIA kit (Phoenix Pharmaceuticals). Briefly, peptide extracts were diluted in RIA buffer, and duplicate samples were assayed. Hcrt-1 levels were determined against a known standard established with known quantities of pure hort-1.

Protein assay. Proteins were quantified using the Folin's method (Lowry et al., 1951) with BSA as standard.

\section{hort-R1 and hort-R2 mRNA expression}

RNA extraction and first-stranded cDNA synthesis. Mice from each genotype were killed by decapitation, and the entire brain was removed. The anterior raphe area was dissected, frozen in liquid nitrogen, and stored at $-80^{\circ} \mathrm{C}$ until use. Total RNA extraction was done using the Stratagene kit (Absolutely RNA Purification kit), according to the instructions of the manufacturer, including removal of genomic DNA by DNase treatment (Stratagene). RNA integrity was checked by agarose gel electrophoresis, and RNA concentrations were determined by spectrophotometric measurements. First-stranded cDNA synthesis $(1 \mu \mathrm{g}$ of total RNA per $20 \mu \mathrm{l}$ reaction) was performed with the SuperScript III Reverse Transcriptase and random primers, as recommended by the manufacturer (Invitrogen).

Quantitative TaqMan reverse transcription-PCR. PCR amplification in triplicate for each sample was performed (ABI Prism 7300; Applied Biosystems) by using ABsolute QPCR Mixes (ABgene) and the Assays-onDemand Gene Expression probes (Applied Biosystems) for hcrt-R1 and hcrt-R2 mRNAs and mRNAs from reporter genes encoding glyceraldehyde 3-phosphate dehydrogenase (GAPDH) and hypoxanthine guanine phosphoribosyltransferase (HPRT). The polymerase activation step at $95^{\circ} \mathrm{C}$ for $15 \mathrm{~min}$ was followed by 40 cycles of $15 \mathrm{~s}$ at $95^{\circ} \mathrm{C}$ and $60 \mathrm{~s}$ at $60^{\circ} \mathrm{C}$. The validity of the results was checked by running appropriate negative controls (substitution of cDNA with water for PCR amplification or omission of reverse transcriptase for the cDNA synthesis step).

Data analysis. The $2^{-\Delta \Delta \mathrm{Ct}}$ method (Livak and Schmittgen, 2001) was used to analyze the relative change in gene expression in $5-H T T^{-1-}$ and 
5-HTT ${ }^{+/+}$mice under control condition or after RS (RQ Study Software version 1.2; Applied Biosystems). All data (expressed in arbitrary units) were analyzed using both GAPDH and HPRT as references.

\section{Statistical analyses}

For experiment 1, RS consequences on the sleep-wakefulness patterns (amount, absolute number, and mean duration of each vigilance state) were first analyzed by a two-way (genotype and stress) ANOVA, with repeated measures over time (states of vigilance over $2 \mathrm{~h}$ segments). When appropriate, additional two-way ANOVAs were performed for stress (repeated measures, RS vs control) and genotype $\left(5-H T T^{-/-}\right.$vs $\left.5-H T T^{+/+}\right)$on specific time slots. The influence of hcrt-R1 pharmacological blockade was assessed by a two-way ANOVA for treatment (repeated measures, SB-334867 vs vehicle) and genotype (5-HTT ${ }^{-1-}$ vs $\left.5-H T T^{+/+}\right)$. For pharmacological treatments combined with RS, data were analyzed independently for mutant and wild-type mice using analyses of covariance (ANCOVAs) to assess the influence of SB-334867 on stress response. The ANCOVAs were performed on W, NREMS, or REMS amounts after RS as dependent variable, pharmacological treatment (SB-334867 vs vehicle) as fixed factor, and the amount of vigilance state before stress as covariate. When appropriate, ANOVAs and ANCOVAs were followed by pairwise comparisons using unpaired or paired $t$ tests as needed. The level of significance was set at $p<0.05$.

For experiment 2, data were analyzed using a two-way (genotype and stress) ANOVA, followed as appropriate by Fisher's protected least significant difference (PLSD) test for pairwise multiple comparisons.

\section{Results}

No significant differences were found between mice obtained from homozygous or heterozygous breeding under basal conditions, as well as after RS. Thus, the data were pooled independently of the breeding condition.

\section{Stress-altered sleep in 5-HTT ${ }^{-/-}$and $5-\mathrm{HTT}^{+/+}$mice: \\ influence of the hypocretinergic system \\ Sleep-wakefulness patterns after restraint stress in $5-\mathrm{HTT}^{-1-}$ and 5-HTT ${ }^{+/+}$mice}

As described previously (Wisor et al., 2003; Alexandre et al., 2006), 5-HTT ${ }^{-/-}$mice exhibited, at baseline, a $45 \%$ increase in REMS amounts compared with wild-type mice $\left(F_{(1,18)}=17.89\right.$, $p<0.001$, over $24 \mathrm{~h}$; data not shown), which was accounted for by a $43 \%$ increase in the number of REMS episodes $\left(F_{(1,18)}=\right.$ 12.20, $p<0.01$ ). This increase was mainly observed during the light period (data not shown). However, REMS enhancement in mutant mice was attenuated in our control conditions [after disconnecting (5:30 P.M.) and connecting again (7:00 P.M.) the recording cables], because it reached only $+19 \%$ over REMS amounts in wild-type mice $\left(F_{(1,14)}=6.40, p<0.05\right)$, suggesting an increased (stress) reactivity to manipulation in $5-H T T^{-/-}$ mice.

The most remarkable changes elicited by 90 min RS on sleepwakefulness patterns concerned REMS characteristics. Although RS induced short-term changes in REMS that were similar in both genotypes, this stress session affected differently REMS in 5-HTT ${ }^{-/-}$and 5-HTT ${ }^{+/+}$mice during late recovery (Fig. 1).

First, RS significantly lengthened REMS latency in both genotypes (stress, $F_{(1,14)}=22.35, p<0.001$; in minutes, control conditions, $22.4 \pm 12.7$ and $12.0 \pm 2.3$ vs RS, $77.9 \pm 13.1$ and $75.1 \pm 24.2$, in $5-H T T^{+/+}$and $5-H T T^{-/-}$mice, respectively), although it did not modify the NREMS latency. Thus, mice of both genotypes exhibited a significant reduction of REMS amounts during the first $2 \mathrm{~h}$ after RS ( $p<0.05$ ) (Figs. 1, $2 A)$. This change was accounted for by a decrease in the number of REMS episodes (stress, $F_{(1,14)}=13.23, p<0.01$ ), with no modification in their mean duration (Fig. $2 \mathrm{~A}$ ). After this $2 \mathrm{~h}$ period,

\section{A}

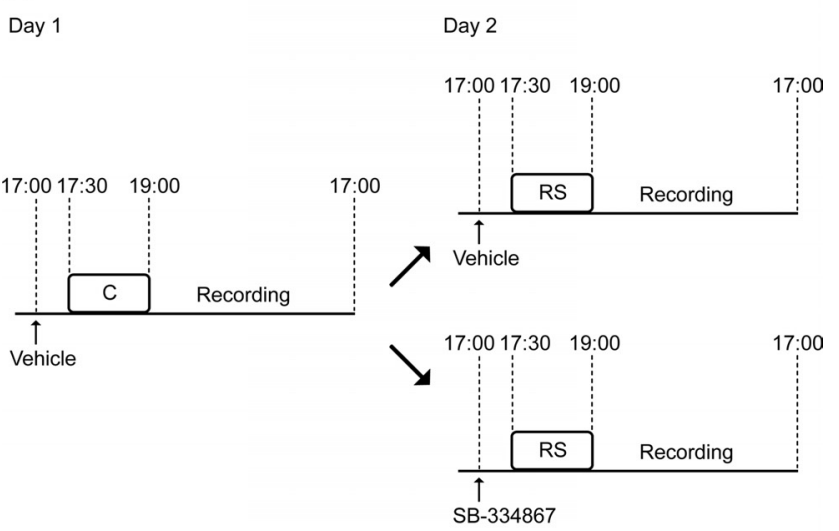

B

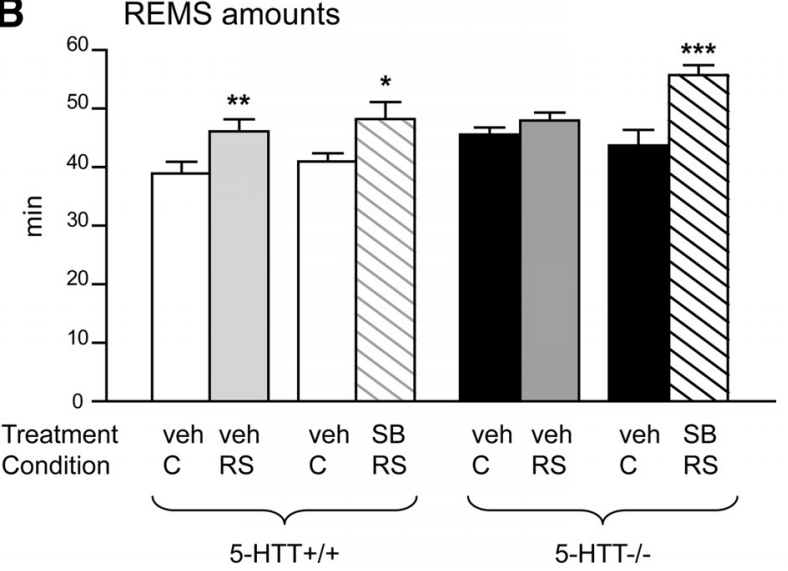

Figure 3. Effects of acute treatment with the hort-R1 antagonist SB-334867 before restraint stress on sleep-wakefulness patterns in $5-\mathrm{HTT}^{+/+}$and $5-H T T^{-/-}$mice. A, Experimental protocol: on the first day of recording (Day 1), 5-HTT ${ }^{+/+}$and $5-H T T^{-/-}$mice were injected with the vehicle at 5:00 P.M. and then subjected to the control (C) procedure for stress by disconnecting (5:30 P.M.) and connecting again (7:00 P.M.) the recording cable to the mouse. Recordings were obtained until 5:00 P.M. the next day. On the following day (Day 2), at 5:00 P.M., $5-\mathrm{HTT}^{+/+}$and 5-HTT${ }^{-/-}$mice were injected with the vehicle or the hort-R1 antagonist SB334867 ( $30 \mathrm{mg} / \mathrm{kg}$, i.p.), and RS was started $30 \mathrm{~min}$ later (at 5:30 P.M.). Recordings of vigilance states were performed as for the preceding control step (Day 1). B, REMS amounts for $8 \mathrm{~h}$ starting at 11:00 P.M. under control conditions (C) or after RS in 5-HTT ${ }^{+/+}$and $5-H T T^{-/-}$mice previously injected with the vehicle (veh) or SB-334867 (SB). Data are the mean \pm SEM of eight to nine animals in each group. ${ }^{*} p<0.05,{ }^{* *} p<0.01$, ${ }^{* * *} p<0.001$, significantly different from the respective control condition; paired Student's $t$ test after ANOVA.

Table 3. Effects of restraint stress on 5-HT and 5-HIAA tissue levels in the hypothalamus of $5-\mathrm{HTT}^{+/+}$and $5-\mathrm{HT}^{-/-}$mice

\begin{tabular}{llllll}
\hline & $5-H T^{+/+}$ & & & $5-H_{T} T^{-/-}$ & \\
\cline { 2 - 3 } \cline { 5 - 6 } & Control & RS & & Control & RS \\
\hline$n$ & 7 & 8 & 7 & 8 \\
5-HT (ng/g tissue) & $959 \pm 30$ & $971 \pm 49$ & & $205 \pm 23^{\# \# \#}$ & $265 \pm 26^{\# \# \#}$ \\
5-HIAA (ng/g tissue) & $394 \pm 13$ & $452 \pm 26$ & & $220 \pm 17^{\# \# \#}$ & $333 \pm 31^{\# \#, * *}$ \\
5-HIAA/5-HT & $0.41 \pm 0.01$ & $0.47 \pm 0.03$ & & $1.08 \pm 0.08^{\# \# \#}$ & $1.26 \pm 0.05^{\# \#, * *}$ \\
\hline
\end{tabular}

Values are expressed as the mean \pm SEM of the number of animals indicated $(n) . \# p<0.01$, \#\#\#p $<0.001$, $5-H T T^{-\prime}$ mutants versus wild-type mice; Fisher's PISD test after ANOVA.

${ }^{*} p<0.05$ and ${ }^{* *} p<0.01$, restraint stress (RS) versus control condition; Fisher's PLSD test after ANOVA.

RS affected differently REMS amounts across genotypes (genotype $\times$ stress interaction, $\left.F_{(1,294)}=8.63, p<0.01\right)$ (Fig. 1). Indeed, the initial drop was followed by an increase in REMS amounts in $5-H T T^{+/+}$mice (stress, $F_{(1,14)}=20.18, p<0.001$; during the 11:00 P.M. to 7:00 A.M. period) (Fig. $2 B$ ) but not in $5-H T T^{-/-}$mutants (genotype $\times$stress interaction, $F_{(1,14)}=8.74$, 
Table 4. Restraint stress-induced activation of hypocretinergic neurons in $5-H \Pi^{+/+}$and $5-H T T^{-/-}$mice

\begin{tabular}{|c|c|c|c|c|c|c|c|c|}
\hline & \multicolumn{4}{|l|}{$t_{0}$} & \multicolumn{4}{|l|}{$t_{0}+5 \mathrm{~h}$} \\
\hline & \multicolumn{2}{|l|}{$5-H T T^{+/+}$} & \multicolumn{2}{|l|}{$5-H T T^{-/-}$} & \multicolumn{2}{|l|}{$5-\mathrm{HTT}^{+/+}$} & \multicolumn{2}{|l|}{$5-H T T^{-/-}$} \\
\hline & Control & $\mathrm{RS}$ & Control & $\mathrm{RS}$ & Control & $\mathrm{RS}$ & Control & $\mathrm{RS}$ \\
\hline$n$ & 7 & 9 & 8 & 8 & 8 & 7 & 8 & 8 \\
\hline Preprohcrt-IR positive neurons & $307 \pm 21$ & $305 \pm 17$ & $296 \pm 11$ & $292 \pm 22$ & $265 \pm 12$ & $287 \pm 16$ & $285 \pm 11$ & $267 \pm 5$ \\
\hline Preprohcrt-IR/c-Fos-IR positive neurons & $61 \pm 19$ & $170 \pm 11^{* * *}$ & $56 \pm 18$ & $156 \pm 14^{* * *}$ & $153 \pm 9$ & $203 \pm 10^{* * *}$ & $167 \pm 12$ & $216 \pm 5^{* * *}$ \\
\hline
\end{tabular}

The data are given as number of labeled neurons per section in the perifornical region of wild-type and mutant mice. For each mouse, among all the observed sections of the perifornical region, the two most intensively labeled sections were analyzed. Control and stressed mice were killed immediately $\left(t_{0}\right)$ or $5 \mathrm{~h}\left(t_{0}+5 \mathrm{~h}\right)$ after RS or control conditions. Values are expressed as the mean \pm SEM of the number of animals indicated $(n)$. ${ }^{* * *} p<0.001$, RS versus control condition; Fisher's PLSD test after ANOVA.

$p<0.05$ ) (Figs. 1, 2B). This REMS increase in wild-type mice was accounted for by an enhancement in the number of episodes, with no change in their mean duration (Fig. 2B).

In addition, RS induced changes in $\mathrm{W}$ and NREMS amounts in both strains (stress; $\mathrm{W}, F_{(1,294)}=12.70, p<0.001$; NREMS, $\left.F_{(1,294)}=15.16, p<0.001\right)$. More specifically, stressed $5-H T T^{+/+}$ mice showed a decrease in $\mathrm{W}(-18 \% ; p<0.001)$ and an increase in NREMS $(+21 \%$; $p<0.001)$ amounts during the $12 \mathrm{~h}$ of the dark period (Fig. 1 and data not shown). Similar trends were observed in 5-HTT ${ }^{-/-}$mice, but corresponding changes were of lower amplitude (W, $-9 \%$; NREMS, +10\%; not significant) (Fig. 1).

Altogether, these data show that $5-H T T^{-/-}$mice exhibited attenuated responses to restraint stress and notably an absence of secondary REMS enhancement. In contrast, on a short-term basis, restraint stress inhibited REMS (reduced amount and number of episodes; increased latency) independently of the mouse genotype.

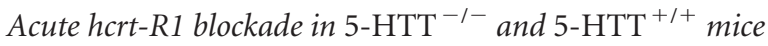
Because hypocretins exert a strong inhibitory influence on REMS, we investigated whether hypocretinergic neurotransmission contributed, at least in part, to the effects of RS on sleepwakefulness patterns in $5-H T T^{-/-}$and $5-H T T^{+/+}$mice. To test this hypothesis, we blocked hcrt-R1 in mice at the time of RS.

Effects of SB-334867 under basal conditions. We first evaluated the consequences of acute blockade of hcrt-R1 with the selective antagonist SB-334867 on sleep and wakefulness patterns in nonstressed $5-\mathrm{HTT}^{-/-}$and $5-\mathrm{HTT}^{+/+}$mice. As observed previously in rats (Smith et al., 2003) and mice (Adamantidis et al., 2007), SB-334867 (30 mg/kg, i.p.) did not significantly affect W, NREMS, or REMS amounts during the first hour (Table 1) and the $12 \mathrm{~h}$ (data not shown) after injection in both wild-type and 5-HTT ${ }^{-/-}$mice. In addition, transitions from sleep to wake were also unchanged by SB-334867 in both strains (data not shown).

Effects of SB-334867 under restraint stress conditions (see protocol in Fig. 3A). The influence of stress on W and NREMS amounts was not significantly affected by previous administration of SB334867 in both $5-H T T^{-/-}$and $5-H T T^{+/+}$mice [first $2 \mathrm{~h}$ after restraint stress (Table 2); 11:00 P.M. to 7:00 A.M.; data not shown].

However, pharmacological blockade of hcrt-R1 had contrasting influences on REMS in the two strains, regarding notably the delayed influences of RS. Thus, injection of SB-334867 30 min before RS (at 5:00 P.M.) (Fig. $3 A$ ) induced in $5-H T T^{-1-}$ mice a significant increase in REMS amounts during the 11:00 P.M. to 7:00 A.M. period (ANCOVA, $F_{(1,13)}=14.95, p<0.01$ ) (Fig. $3 B$ ). Conversely, in wild-type mice, REMS enhancement after RS was occurring similarly with or without previous pharmacological blockade of hcrt-R1 by SB-334867 (ANCOVA for treatment,
$F_{(1,14)}=0.14, p=0.72$ ) (Fig. $3 B$ ). It should be noted, however, that $5-H T T^{+/+}$mice exhibited an attenuated stress-altered sleep after treatment with vehicle compared with naive animals, notably for the REMS increase (Fig. $3 B$ vs Fig. $2 B$ ). This could have been a consequence of the experimental paradigm that imposed vehicle injection on the control day (control condition; see Materials and Methods). As observed previously, the dramatic decrease in REMS amounts during the first $2 \mathrm{~h}$ after RS occurred in both genotypes independently of the pharmacological treatment (vehicle group, $F_{(1,15)}=47.87, p<0.0001$; SB-334867 group, $\left.F_{(1,14)}=16.04, p<0.01\right)$ (Table 2).

Therefore, in 5-HTT ${ }^{-/-}$mice, the pharmacological blockade of hcrt-R1 before stress restored the delayed increase in REMS amounts that was regularly observed in $5-\mathrm{HTT}^{+/+}$mice after RS.

\section{Effects of restraint stress on serotonergic neurotransmission} in $5-\mathrm{HTT}^{-/-}$and $5-\mathrm{HTT}^{+/+}$mice

5-HT and 5-HIAA tissue levels after restraint stress in 5-HTT ${ }^{-1-}$ and $5-\mathrm{HTT}^{+/+}$mice

Stress has been reported to excite serotonergic neurons in rats and mice (Chaouloff, 1993; Cullinan et al., 1995; Grahn et al., 1999; Roche et al., 2003). Accordingly, we examined whether 90 min RS affected differentially 5-HT and 5-HIAA tissue levels in 5-HTT ${ }^{-/-}$and $5-\mathrm{HTT}^{+/+}$mice by using HPLC.

As described previously in several forebrain structures (Fabre et al., 2000; Kim et al., 2005), 5-HT levels in the hypothalamus of $5-H T T^{-1-}$ mutants were strongly decreased (approximately $-80 \%$ compared with $5-\mathrm{HTT}^{+/+}$mice) both under control condition and after $\operatorname{RS}\left(F_{(1,26)}=449.04, p<0.001\right)$ (Table 3). A less pronounced decrease $(-26$ to $-40 \%)$ was observed for 5-HIAA levels $\left(F_{(1,26)}=37.44, p<0.001\right)$ (Table 3$)$. These genotypedependent changes resulted in marked increases of 5-HIAA/ 5 -HT ratios in 5-HTT ${ }^{-1-}$ mutants (approximately $+160 \%$ over those in 5-HTT ${ }^{+/+}$mice; $\left.F_{(1,26)}=236.41, p<0.001\right)$ (Table 3).

In $5-H T T^{-/-}$mice, RS was found to increase significantly the tissue levels of 5-HIAA in the hypothalamus $\left(+51 \% ; F_{(1,26)}=\right.$ 12.76, $p<0.01$ ) (Table 3) and nonsignificantly those of 5-HT $\left(F_{(1,26)}=1.12, p=0.30\right)$. RS also increased significantly the 5 -HIAA/5-HT ratio $(+17 \%$ in the mutants). In contrast, these changes did not reach statistical significance in $5-\mathrm{HTT}^{+/+}$mice (Table 3). Accordingly, RS activated the hypothalamic serotonergic neurotransmission to a higher degree in $5-\mathrm{HTT}^{-/-}$mutants than in $5-H T T^{+/+}$mice.

\section{Effects of restraint stress on hypocretinergic}

\section{neurotransmission in 5-HTT ${ }^{-/-}$and $5-H T T^{+/+}$mice}

Activation of hypocretin neurons

Stress has also been reported to excite hypocretin neurons in rats and mice (Estabrooke et al., 2001; Espana et al., 2003; WinskySommerer et al., 2004). We therefore examined the effects of a 90 
A

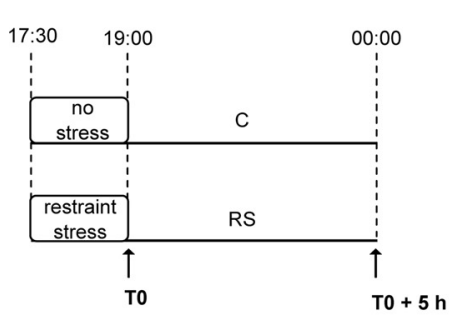

B

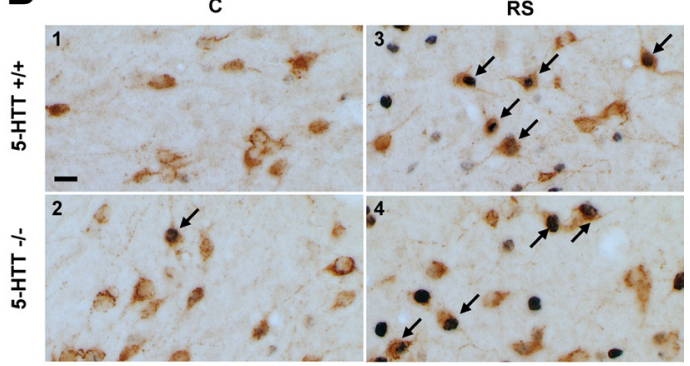

C
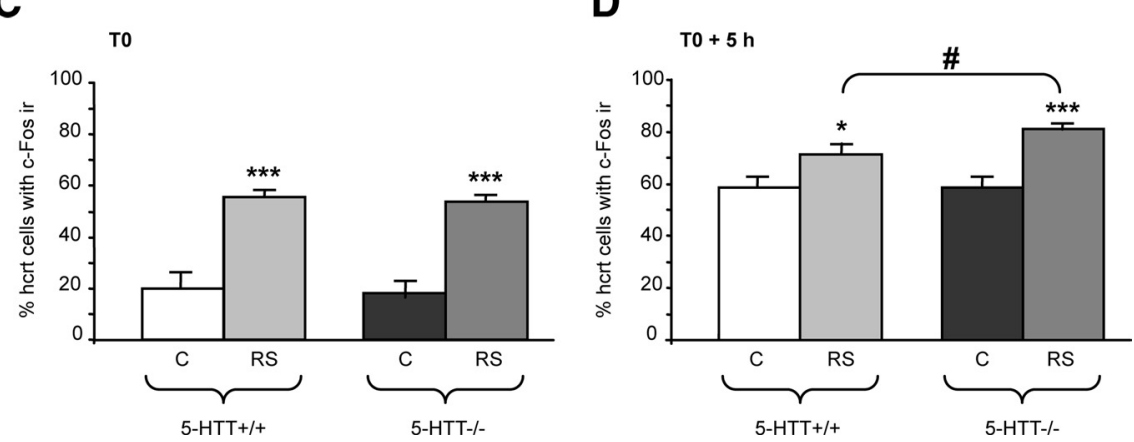

Figure 4. Activation of hypocretin neurons after restraint stress in $5-\mathrm{HTT}^{+/+}$and $5-\mathrm{HTT}^{-/-}$mice. $\mathrm{A}$, Schematic representation of the experimental protocol. The activation of hypocretin neurons has been measured in $5-\mathrm{HTT}^{+/+}$and $5-\mathrm{HTT}^{-/-}$mice immediately $\left(t_{0}\right)$ or $5 \mathrm{~h}\left(t_{0}+5 \mathrm{~h}\right)$ after the end of $90 \mathrm{~min} \mathrm{RS}$ and in nonstressed (control; C) paired mice killed at the same time. $\boldsymbol{B}$, Representative immunocytochemical labeling at the level of the perifornical area of the lateral hypothalamus showing few

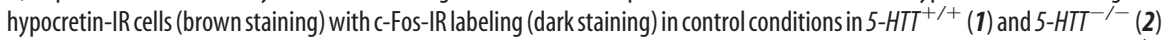
mice. RS induced a strong and immediate $\left(t_{0}\right)$ increase in the number of $c$-Fos-IR nuclei in hypocretin-IR neurons in both $5-H T T^{+/+}$ (3) and 5-HTT ${ }^{-1-}$ (4) mice. Black arrows, c-Fos-IR and hypocretin-IR neurons. Scale bar, $10 \mu$ m. C, D, Percentage of hypocretin-IR neurons with C-Fos-IR labeling in control conditions (C) and after RS in $5-\mathrm{HTT}^{+/+}$and $5-\mathrm{HTT}^{-/-}$mice. Mice were killed immediately $\left(t_{0} ; \boldsymbol{C}\right)$ or $5 \mathrm{~h}\left(t_{0}+5 \mathrm{~h} ; \boldsymbol{D}\right)$ after RS or control conditions. Data are expressed as the mean \pm SEM of seven to eight mice in each group. ${ }^{*} p<0.05,{ }^{* * *} p<0.001$, significantly different from the control condition; ${ }^{*} p<0.05,5-H T T^{-1-}$ versus wild-type mice; Fisher's PLSD test after ANOVA.

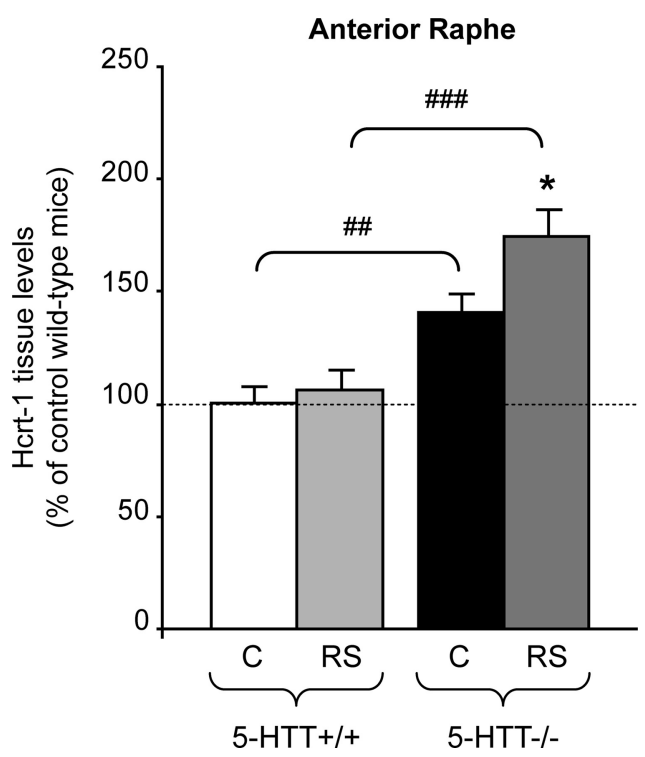

Figure 5. Effects of restraint stress on hcrt-1 levels in the anterior raphe area of 5-HTT ${ }^{+/+}$ and $5-H T T^{-1-}$ mice. Hcrt-1 tissue levels were measured in the anterior raphe area of $5-H T T^{+/+}$and $5-H T T^{-/-}$mice in control condition (C) or immediately after RS. Hert-1 tissue levels are expressed as percentage of values in nonstressed $5-\mathrm{HTT}^{+/+}$mice. Absolute values were as follows (ng/ $\mu$ g protein): $1.46 \pm 0.11$ (control condition in $5-H T T^{+/+}$), $1.54 \pm 0.13$ (RS in $5-H T T^{+/+}$), $2.09 \pm 0.11$ (control condition in $5-H T T^{-/-}$), and $2.56 \pm 0.16$ (RS in $5-\mathrm{HTT}^{-/-}$). Data are the mean \pm SEM of seven to nine animals in each group. ${ }^{*} p<0.05$, significantly different from the control condition; ${ }^{\# \#} p<0.01,{ }^{\# \# \#} p<0.001,5-H T T^{-/-}$versus wild-type mice; Fisher's PLSD test after ANOVA. min RS session on hypocretin neuron activity in $5-H T T^{-/-}$versus $5-H T T^{+/+}$ mice by using the $\mathrm{c}$-Fos marker.

Under control conditions (at 7:00 P.M.; control $t_{0}$ ), 5-HTT ${ }^{-/-}$mice showed no differences in the total number of hypocretin neurons in the perifornical region of the hypothalamus compared with wild-type mice (Table 4). In both strains, the number of hypocretin neurons expressing c-Fos was markedly increased (by $\sim 2.8$-fold) immediately after RS (RS $\left.t_{0}\right)\left(F_{(1,28)}=45.77, p<0.001\right)$ (see Fig. $5 B$, Table 4 ), whereas the total number of hypocretin neurons remained unchanged $\left(F_{(1,28)}=0.02, p=0.88\right)$ (Table 4). As a consequence, stressed mice of both genotypes exhibited a greater percentage of double-labeled neurons than respective unstressed controls $\left(F_{(1,28)}=65.60, p<\right.$ 0.001) (Fig. 4C). Furthermore, RS activated hypocretin neurons to the same degree in both strains (Fig. 4C).

To determine the time course of hypocretin neuron activation after RS, some mutant and wild-type mice were returned to their home cage after RS and were anesthetized for intracardiac perfusion with PFA at midnight $\left(t_{0}+5 \mathrm{~h}\right)$.

As shown previously in rats (Estabrooke et al., 2001), hypocretin neuron activity varied across the light/dark cycle, with higher levels of activity detected during the dark period as expected from wake-active neurons (M. G. Lee et al., 2005; Mileykovskiy et al., 2005; Takahashi et al., 2008). Accordingly, we observed a robust increase (by approximately threefold) in the percentage of c-Fosexpressing hypocretin neurons in nonstressed control mice of both genotypes killed during the dark period (0:00, control $t_{0}+$ $5 \mathrm{~h})$ compared with mice killed at the end of the light period (7:00 P.M., control $t_{0} ; F_{(1,27)}=66.78, p<0.001$ ). However, the total number of hypocretin neurons was not significantly different at $t_{0}+5 \mathrm{~h}$ compared with $t_{0}$ in both $5-\mathrm{HTT}^{+/+}$and 5-HTT ${ }^{-/-}$mice (Table 4).

Five hours after restraint stress (RS $t_{0}+5 \mathrm{~h}$ ), the number of hypocretin neurons expressing c-Fos was still increased in both strains compared with their respective nonstressed controls (stress, $F_{(1,27)}=27.51, p<0.001$ ) (Table 4). Accordingly, the percentage of double-labeled neurons was increased by RS in both strains (stress effect, $F_{(1,27)}=26.99, p<0.001$ ) (Fig. $4 D$ ). Interestingly, this RS effect was almost twice as large in $5-H T T^{-/-}$ mutants $(+38.1 \%)$ as in $5-H T T^{+/+}$mice $(+22.5 \%)$.

In summary, RS produced an immediate and a long-lasting activation of hypocretin neurons in both $5-H T T^{-/-}$and 5-HTT ${ }^{+/+}$mice. However, this long-lasting influence of RS was larger in $5-\mathrm{HTT}^{-/}$mice.

Hcrt-1 tissue levels after restraint stress in the anterior raphe area of $5-\mathrm{HTT}^{-1-}$ and $5-\mathrm{HTT}^{+/+}$mice

Hypocretinergic neurons project to the anterior raphe nuclei (Peyron et al., 1998; H. S. Lee et al., 2005; Wang et al., 2005). Thus, hcrt-1 tissue levels were measured, by radioimmunoassay, in the anterior raphe area, which includes 5-HT cell bodies from 


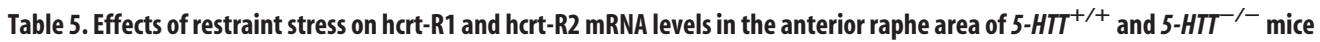

\begin{tabular}{|c|c|c|c|c|}
\hline & \multicolumn{2}{|l|}{$5-H T T^{+/+}$} & \multicolumn{2}{|l|}{$5-H T T^{-1-}$} \\
\hline & Control & RS & Control & RS \\
\hline$n$ & 7 & $6-7$ & 7 & 7 \\
\hline hert-R1 mRNA (A.U.) & $0.79 \pm 0.07$ & $1.21 \pm 0.20 *(+53 \%)$ & $0.68 \pm 0.08$ & $1.14 \pm 0.15^{*}(+68 \%)$ \\
\hline hert-R2 mRNA (A.U.) & $1.49 \pm 0.17$ & $1.43 \pm 0.17(-4 \%)$ & $1.41 \pm 0.05$ & $1.45 \pm 0.11(+3 \%)$ \\
\hline
\end{tabular}

Values [relative quantity, mean \pm SEM of the number of animals indicated ( $n$ )] are expressed in arbitrary units (A.U.) after normalization to an endogenous reference gene (GAPDH). Normalization with HPRT as endogenous reference gene (see Materials and Methods) gave similar results. ${ }^{*} p<0.05$, RS versus control condition; Fisher's PLSD test after ANOVA.

the dorsal and the median raphe nuclei. The two-way ANOVA indicates overall effects of genotype $\left(\mathrm{F}_{(1,26)}=34.38, p<0.001\right)$ and stress $\left(F_{(1,26)}=4.71, p<0.05\right)$. As illustrated in Figure 5, under control conditions, hcrt-1 tissue levels were significantly higher in 5-HTT ${ }^{-/-}$mutants compared with wild-type mice. Although RS did not affect hcrt-1 levels in 5-HTT ${ }^{+/+}$mice, a significant increase was observed in stressed $5-H T T^{-/-}$mutants $\left(+25 \%\right.$ over nonstressed control $5-H T T^{-1-}$ mice). As a result, after stress, hcrt-1 levels were 66\% higher $(p<0.001)$ in $5-H T T^{-/-}$mutants than in paired $5-H T T^{+/+}$mice (Fig. 5).

hcrt-R1 and hort-R2 mRNA levels

To test whether changes in 5-HT neurotransmission and/or RS may influence hort receptor expression, hcrt-R1 and hcrt-R2 mRNA levels were determined in the anterior raphe area after 90 min RS and under control conditions.

As reported in Table 5, the levels of hort-R1 mRNA in the anterior raphe area were not different in $5-H T T^{-1-}$ and wildtype mice under control conditions $\left(F_{(1,23)}=0.47, p=0.50\right)$. An RS-induced increase in hcrt-R1 mRNA levels was observed in both $5-H T T^{-1-}(+68 \%)$ and wild-type $(+53 \%)$ mice $\left(F_{(1,23)}=\right.$ $11.83, p<0.01)$ (Table 5). In contrast, in all the conditions examined, hcrt-R2 mRNA expression remained unchanged (Table 5).

The RS-induced increase in hcrt-R1 mRNA expression in the anterior raphe area suggests that hypocretinergic neurotransmission may be enhanced in $5-H T T^{-1-}$ and wild-type mice in response to RS.

\section{Discussion}

The present data show that genetically driven loss of the 5-HTT function produces impaired sleep modulations by stress. These impairments appeared to be causally related to an enhanced hypocretinergic neurotransmission because the sleep response to stress in $5-H T T^{-/-}$mutant mice could be normalized by blocking the hypocretin type 1 receptor. These results emphasize the role of hypocretin neurons in the disrupted stress response consecutive to 5-HTT deficiency in mice.

\section{Mutant mice lacking the 5-HTT show an altered sleep homeostasis after restraint stress}

It is generally agreed that sleep quality and duration depend on events taking place during wakefulness. In rodents, stress induces a marked arousal and has subsequently sleep-promoting influences that mainly concern REMS (Rampin et al., 1991; Marinesco et al., 1999; Boutrel et al., 2002). In the present study, 90 min RS session induced strong adaptations of the sleep-wakefulness patterns in wild-type male mice of the CD-1 background as described previously in CD1 females (Popa et al., 2008) and other mouse strains (Meerlo et al., 2001; Boutrel et al., 2002; Léna et al., 2004): initially, a dramatic decrease in REMS amounts that lasted for $2 \mathrm{~h}$ after RS, and, secondarily, an increase in REMS and NREMS amounts at the expense of wakefulness.

Compared with wild-type mice, $5-H T T^{-/-}$mutants displayed at baseline larger REMS amounts as shown previously (Wisor et al., 2003; Alexandre et al., 2006), but they exhibited a blunted sleep response to stress that was mainly characterized by the absence of the secondary REMS increase. This suggests that there is no linear relation between spontaneous and stress-triggered REMS amounts, in agreement with other models (Popa et al., 2008). The absence of the delayed increase in REMS after RS, which had been also observed in female $5-H T T^{-/-}$mice (Popa et al., 2008), was associated here with a higher RS-induced activation of serotonergic neurons in $5-H T T^{-1-}$ mutants compared with wild-type mice (Table 3 ). Previous studies already showed that 5-HT neurons are critical for mediating the delayed influence of stress on sleep. Thus, in rats, the 5-HT outflow in the hypothalamus is strongly enhanced after RS, and mimicking such enhancement by direct DR electrical stimulation is sufficient to produce a delayed REMS increase (Houdouin et al., 1991a,b). However, because the initial decrease in REMS amounts after RS was maintained in $5-H T T^{-/-}$mice, it can be inferred that only secondary changes in REMS are controlled by 5-HT neurotransmission. Interestingly, the inhibition of 5-HT synthesis (Sinha, 2006) or the absence of $5-\mathrm{HT}_{1 \mathrm{~A}}$ or $5-\mathrm{HT}_{1 \mathrm{~B}}$ receptors (Boutrel et al., 2002; Adrien et al., 2004) also abolishes the REMS induction by RS.

Our findings in $5-\mathrm{HTT}^{-/-}$mice are in line with previous data indicating that these mutants exhibit a number of stress-related phenotypical changes: enhanced neuroendocrine responses to stress either on the CD-1 (Li et al., 1999) or the C57BL/6J (Tjurmina et al., 2002) background and exaggerated behavioral responses to mild stressor, including saline injections (Li et al., 1999; Tjurmina et al., 2002). In addition, 5-HTT ${ }^{-1}$ mice present an exacerbated depression-like behavior after repeated exposure to forced swim stress (Wellman et al., 2007) and enhanced sensitivity to a single predator exposure, which has been proposed as a model for posttraumatic stress disorders (Adamec et al., 2006). Thus, the impaired sleep homeostasis in response to stress found here in these mutants is consistent with the hypothesis that 5-HTT deficiency leads to alterations in the capacity to adapt to environmental stress (Wellman et al., 2007). Also in humans, the low-expressing polymorphic variant of the promoter region of the HTT gene has been associated with an elevated rate of posttraumatic stress disorders (H. J. Lee et al., 2005) and heightened risk of major depression in response to stressful life events (Caspi and Moffitt, 2006).

\section{Hypocretin controls sleep homeostasis in \\ 5-HTT-deficient mice}

Numerous studies demonstrated that reciprocal influences exist between hypocretins and the HPA axis (Spinazzi et al., 2006). Administration of hcrt-1 activates the HPA axis (Hagan et al., 1999; Jászberényi et al., 2000; Kuru et al., 2000; Al-Barazanji et al., 2001; Russell et al., 2001), and, conversely, stress increases preprohcrt mRNA contents in mice (Reyes et al., 2003) and activates hypocretin neurons in both rats and mice (Estabrooke et al., 2001; Espana et al., 2003; Winsky-Sommerer et al., 2004). In agreement with these data, we found here that RS activated hypocretinergic neurotransmission in both wild-type and $5-H T T^{-/-}$ 
mice (as indicated by c-Fos labeling and hcrt-R1 mRNA expression). However, this effect was stronger in mutant mice as reflected by the larger long-lasting influence of RS on hypocretin neuron activation and hcrt- 1 contents. Thus, at baseline, $5-\mathrm{HTT}^{-{ }^{-}} \mathrm{mu}-$ tant mice exhibited in the anterior raphe area higher tissue levels of hcrt-1 than wild-type mice, suggesting that 5-HT may affect hcrt-1 production and/or degradation. After RS, these alterations were exacerbated in $5-H T T^{-1-}$ mice as indicated by the additional increase in hcrt-1 tissue contents. However, the finding that hypocretinergic neurotransmission is enhanced in $5-\mathrm{HTT}^{-/-}$ mice, notably after RS, is apparently contradictory with the well established inhibitory role of 5-HT on hypocretin neuron activity through 5- $\mathrm{HT}_{1 \mathrm{~A}}$ receptor activation (Muraki et al., 2004). Indeed, this discrepancy might be accounted for by the decreased density and function of 5- $\mathrm{HT}_{1 \mathrm{~A}}$ receptors in the hypothalamus of 5-HTT ${ }^{-/-}$mice (Li et al., 1999, 2000; Alexandre et al., 2006), thereby causing a decreased inhibitory influence of 5-HT on hypocretin neurons. In turn, the hypocretinergic tone on 5-HT neurons would be enhanced, notably through elevated hort- 1 contents in the anterior raphe area of $5-H T T^{-/-}$mice. Thus, our findings lead to the idea that the REMS altered response in $5-\mathrm{HTT}^{/-}$mice might be related to an enhanced hypocretinergic neurotransmission in 5-HTT ${ }^{-1-}$ mice in response to stress.

This hypothesis is strongly supported by our observation that, although it had no impact on its own, blockade of hort-R1 during stress in mutants rescued almost completely the delayed increase in REMS after stress, thereby mimicking the wild-type phenotype. This finding suggests that, in $5-H T T^{-/-}$mice, the impaired REMS response to stress is mediated, at least in part, by hypocretin neurons via hcrt-R1 receptors. This impairment seems specific to mutants because, in wild-type mice, acute blockade of hcrt-R1 before stress did not modify the sleep response to RS. Thus, the adaptive regulation of sleep that follows an acute stress challenge requires a balance between the hypocretin and the 5 -HT systems, which is impaired in $5-H_{T T}^{-/-}$mice. Here, we showed that hort-R1 are involved in this balance, but this does not exclude a role for hcrt-R2 also. Indeed, hcrt-R2 are present on 5-HT neurons and may modulate the HPA axis during the stress response (Chang et al., 2007). This latter point needs to be addressed with selective hcrt-R2 antagonists, but such ligands are not yet available. Finally, although other components of the 5-HT neurotransmission might be involved, directly or indirectly, in our paradigm, we propose a key role for $5-\mathrm{HT}_{1 \mathrm{~A}}$ receptors in the deficit of REMS homeostasis after stress in $5-\mathrm{HTT}^{-/-}$mutants (Fig. 6). Indeed, (1) as observed in the latter mutants, knock-out mice lacking the 5- $\mathrm{HT}_{1 \mathrm{~A}}$ receptors exhibit no delayed REMS increase after RS (Boutrel et al., 2002), and (2) 5- $\mathrm{HT}_{1 \mathrm{~A}}$ receptors are downregulated and/or desensitized in the DR (Fabre et al., 2000; Bouali et al., 2003) and the hypothalamus (Li et al., 1999, 2000; Alexandre et al., 2006) of 5-HTT ${ }^{-1-}$ mutants. However, this model (Fig. 6) does not exclude a role for $5-\mathrm{HT}_{1 \mathrm{~B}}$ receptors through regulation of 5-HT release at the terminal level, because $5-\mathrm{HT}_{1 \mathrm{~B}}$ knock-out mice also exhibit a deficit in REMS homeostasis after RS (Adrien et al., 2004).

As mentioned above, in addition to sleep disorders, 5-HTT ${ }^{-1-}$ mice exhibit several behavioral alterations, including increased anxiety- and depression-like behaviors and vulnerability to stress (Hariri and Holmes, 2006). Conversely, mice with increased 5-HT reuptake exhibit a low anxiety-like phenotype (Jennings et al., 2006). Whether such behavioral changes may also be related to alterations in hypocretinergic neurotransmission is a relevant question to be addressed notably because several other animal models with sleep and/or behavioral alterations also exhibit

\section{A wild-type mice}

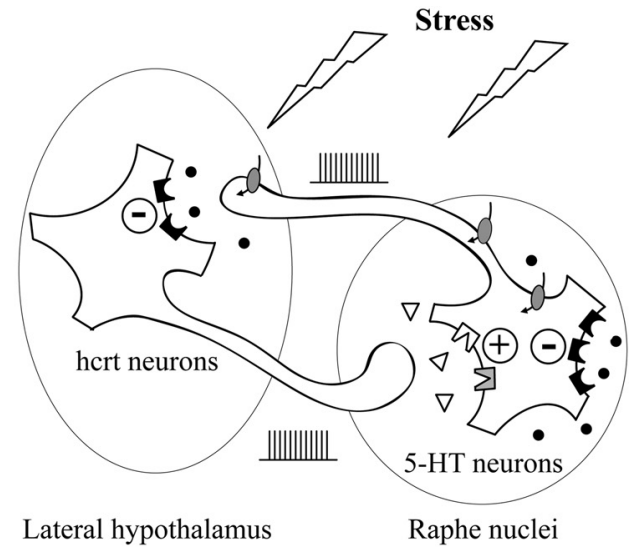

B 5-HTT-/- mutant mice

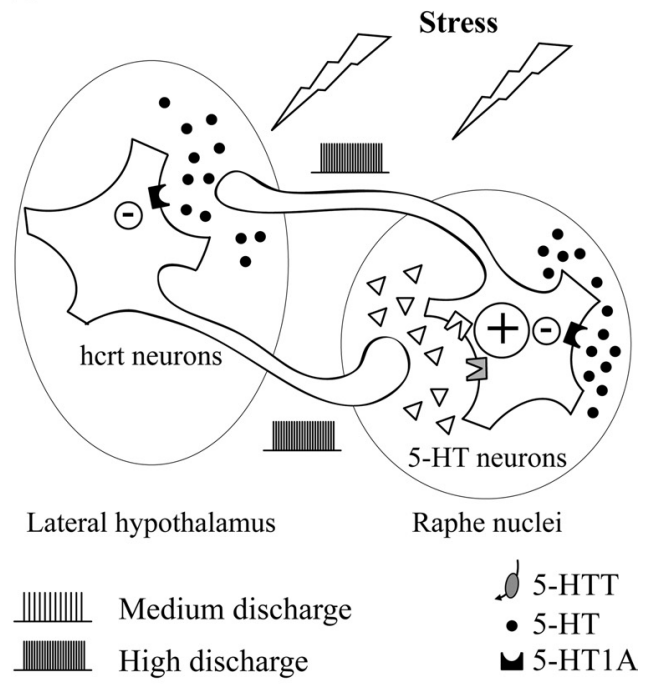

$\triangle$ Hert

$\triangle$ Hcrt-R1

M Hort-R2

Figure 6. Model of hort-5-HT interactions in 5-HTT ${ }^{-/-}$mutants and 5-HTT ${ }^{+/+}$wild-type mice: influence of stress. $\boldsymbol{A}$, In wild-type mice, restraint stress activates both hert and 5-HT neurons. Whereas hort excites 5-HT neurons through hort- $\mathrm{R} 1$ and hort- $\mathrm{R} 2$ receptors, 5 -HT inhibits the activity of hort neurons through $5-\mathrm{HT}_{1 \mathrm{~A}}$ receptors. In this model, the inhibitory influence of the indolamine on hort and 5-HT neurons (via 5-HT ${ }_{1 \mathrm{~A}}$ autoreceptors) will result in a new steady-state level and would allow the stress-induced sleep response (i.e., the delayed increase

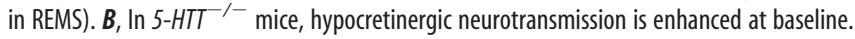
Such activation can result from adaptive changes in serotonergic neurotransmission and, notably, $5-\mathrm{HT}_{1 \mathrm{~A}}$ receptor downregulation and/or desensitization in the hypothalamus that is triggered by the excess of extracellular $5-\mathrm{HT}$ in mutant mice. In addition, these mice exhibit strong downregulation and desensitization of $5-\mathrm{HT}_{1 \mathrm{~A}}$ autoreceptors in the dorsal raphe nucleus. We propose that this reduced $5-\mathrm{HT}_{1 \mathrm{~A}}$-mediated inhibitory influence of $5-\mathrm{HT}$ on both $5-\mathrm{HT}$ and hort neurons contributes to higher RS-induced enhancement of hypocretinergic and serotonergic neurotransmissions in 5-HTT ${ }^{-/-}$versus wild-type mice. Such alterations of hort-5-HT interactions may account for the maladaptive REMS response to stress in $5-H T T^{-/-}$mice (i.e., the absence of the delayed increase in REMS), because pharmacological blockade of hcrt-R1 restored the delayed increase in REMS normally observed after restraint stress.

changes in the hypocretinergic system (Taheri et al., 2001; Allard et al., 2004; Feng et al., 2007; Lutter et al., 2008). Interestingly, studies in humans showed that hort-1 levels in the CSF (1) negatively correlate with symptoms such as lassitude in suicide attempters (Brundin et al., 2007), (2) are slightly increased in depressed patients, and (3) are reduced by treatment with selective serotonin reuptake inhibitors (Salomon et al., 2003). Thus, as 
suggested in the present study, hypocretin neurons, which are under the influence of 5-HT, may modulate the emotional state.

\section{Conclusion}

Our study using 5-HTT ${ }^{-/-}$mice is reminiscent of human pathology in which low functioning of the 5-HTT is associated with increased vulnerability to stress and heightened risk of developing depression. Accordingly, the hypocretin/5-HT interactions would be involved not only in sleep regulation but also in the control of mood- and emotion-driven functions and may underlie psychoaffective disorders.

\section{References}

Adamantidis AR, Zhang F, Aravanis AM, Deisseroth K, de Lecea L (2007) Neural substrates of awakening probed with optogenetic control of hypocretin neurons. Nature 450:420-424.

Adamec R, Burton P, Blundell J, Murphy DL, Holmes A (2006) Vulnerability to mild predator stress in serotonin transporter knockout mice. Behav Brain Res 170:126-140.

Adrien J, Alexandre C, Boutrel B, Popa D (2004) Contribution of the "knock-out" technology to understanding the role of serotonin in sleep regulations. Arch Ital Biol 142:369-377.

Al-Barazanji KA, Wilson S, Baker J, Jessop DS, Harbuz MS (2001) Central orexin-A activates hypothalamic-pituitary-adrenal axis and stimulates hypothalamic corticotropin releasing factor and arginine vasopressin neurones in conscious rats. J Neuroendocrinol 13:421-424.

Alexandre C, Popa D, Fabre V, Bouali S, Venault P, Lesch KP, Hamon M, Adrien J (2006) Early life blockade of 5-hydroxytryptamine 1A receptors normalizes sleep and depression-like behavior in adult knock-out mice lacking the serotonin transporter. J Neurosci 26:5554-5564.

Allard JS, Tizabi Y, Shaffery JP, Trouth CO, Manaye K (2004) Stereological analysis of the hypothalamic hypocretin/orexin neurons in an animal model of depression. Neuropeptides 38:311-315.

Bengel D, Murphy DL, Andrews AM, Wichems CH, Feltner D, Heils A, Mössner R, Westphal H, Lesch KP (1998) Altered brain serotonin homeostasis and locomotor insensitivity to 3, 4-methylenedioxymethamphetamine ("Ecstasy") in serotonin transporter-deficient mice. Mol Pharmacol 53:649-655.

Bouali S, Evrard A, Chastanet M, Lesch KP, Hamon M, Adrien J (2003) Sex hormone-dependent desensitization of 5-HT1A autoreceptors in knockout mice deficient in the 5-HT transporter. Eur J Neurosci 18:2203-2212.

Boutrel B, Monaca C, Hen R, Hamon M, Adrien J (2002) Involvement of 5-HT1A receptors in homeostatic and stress-induced adaptive regulations of paradoxical sleep: studies in 5-HT1A knock-out mice. J Neurosci 22:4686-4692.

Brown RE, Sergeeva O, Eriksson KS, Haas HL (2001) Orexin A excites serotonergic neurons in the dorsal raphe nucleus of the rat. Neuropharmacology 40:457-459.

Brown RE, Sergeeva OA, Eriksson KS, Haas HL (2002) Convergent excitation of dorsal raphe serotonin neurons by multiple arousal systems (orexin/hypocretin, histamine and noradrenaline). J Neurosci 22:8850-8859.

Brundin L, Björkqvist M, Petersén A, Träskman-Bendz L (2007) Reduced orexin levels in the cerebrospinal fluid of suicidal patients with major depressive disorder. Eur Neuropsychopharmacol 17:573-579.

Caspi A, Moffitt TE (2006) Gene-environment interactions in psychiatry: joining forces with neuroscience. Nat Rev Neurosci 7:583-590.

Chang H, Saito T, Ohiwa N, Tateoka M, Deocaris CC, Fujikawa T, Soya H (2007) Inhibitory effects of an orexin-2 receptor antagonist on orexin Aand stress-induced ACTH responses in conscious rats. Neurosci Res $57: 462-466$.

Chaouloff F (1993) Physiopharmacological interactions between stress hormones and central serotonergic systems. Brain Res Brain Res Rev 18:1-32.

Collin M, Bäckberg M, Onnestam K, Meister B (2002) 5-HT1A receptor immunoreactivity in hypothalamic neurons involved in body weight control. Neuroreport 13:945-951.

Cullinan WE, Herman JP, Battaglia DF, Akil H, Watson SJ (1995) Pattern and time course of immediate early gene expression in rat brain following acute stress. Neuroscience 64:477-505.

de Lecea L, Kilduff TS, Peyron C, Gao X, Foye PE, Danielson PE, Fukuhara C, Battenberg EL, Gautvik VT, Bartlett FS 2nd, Frankel WN, van den Pol AN,
Bloom FE, Gautvik KM, Sutcliffe JG (1998) The hypocretins: hypothalamusspecific peptides with neuroexcitatory activity. Proc Natl Acad Sci USA 95:322-327.

España RA, Valentino RJ, Berridge CW (2003) Fos immunoreactivity in hypocretin-synthesizing and hypocretin-1 receptor-expressing neurons: effects of diurnal and nocturnal spontaneous waking, stress and hypocretin-1 administration. Neuroscience 121:201-217.

Estabrooke IV, McCarthy MT, Ko E, Chou TC, Chemelli RM, Yanagisawa M, Saper CB, Scammell TE (2001) Fos expression in orexin neurons varies with behavioral state. J Neurosci 21:1656-1662.

Fabre V, Beaufour C, Evrard A, Rioux A, Hanoun N, Lesch KP, Murphy DL, Lanfumey L, Hamon M, Martres MP (2000) Altered expression and functions of serotonin 5-HT1A and 5-HT1B receptors in knock-out mice lacking the 5-HT transporter. Eur J Neurosci 12:2299-2310.

Feng P, Vurbic D, Wu Z, Strohl KP (2007) Brain orexins and wake regulation in rats exposed to maternal deprivation. Brain Res 1154:163-172.

Grahn RE, Will MJ, Hammack SE, Maswood S, McQueen MB, Watkins LR, Maier SF (1999) Activation of serotonin-immunoreactive cells in the dorsal raphe nucleus in rats exposed to an uncontrollable stressor. Brain Res 826:35-43.

Hagan JJ, Leslie RA, Patel S, Evans ML, Wattam TA, Holmes S, Benham CD, Taylor SG, Routledge C, Hemmati P, Munton RP, Ashmeade TE, Shah AS, Hatcher JP, Hatcher PD, Jones DN, Smith MI, Piper DC, Hunter AJ, Porter RA, Upton N (1999) Orexin A activates locus coeruleus cell firing and increases arousal in the rat. Proc Natl Acad Sci USA 96:10911-10916.

Hamon M, Fattaccini CM, Adrien J, Gallissot MC, Martin P, Gozlan H (1988) Alterations of central serotonin and dopamine turnover in rats treated with ipsapirone and other 5-hydroxytryptamine1A agonists with potential anxiolytic properties. J Pharmacol Exp Ther 246:745-752.

Hariri AR, Holmes A (2006) Genetics of emotional regulation: the role of the serotonin transporter in neural function. Trends Cogn Sci 10:182-191.

Houdouin F, Cespuglio R, Gharib A, Sarda N, Jouvet M (1991a) Detection of the release of 5-hydroxyindole compounds in the hypothalamus and the $\mathrm{n}$. raphe dorsalis throughout the sleep-waking cycle and during stressful situations in the rat: a polygraphic and voltammetric approach. Exp Brain Res 85:153-162.

Houdouin F, Cespuglio R, Jouvet M (1991b) Effects induced by the electrical stimulation of the nucleus raphe dorsalis upon hypothalamic release of 5-hydroxyindole compounds and sleep parameters in the rat. Brain Res 565:48-56.

Jászberényi M, Bujdosó E, Pataki I, Telegdy G (2000) Effects of orexins on the hypothalamic-pituitary-adrenal system. J Neuroendocrinol 12:1174-1178.

Jennings KA, Loder MK, Sheward WJ, Pei Q, Deacon RM, Benson MA, Olverman HJ, Hastie ND, Harmar AJ, Shen S, Sharp T (2006) Increased expression of the 5-HT transporter confers a low-anxiety phenotype linked to decreased 5-HT transmission. J Neurosci 26:8955-8964.

Kim DK, Tolliver TJ, Huang SJ, Martin BJ, Andrews AM, Wichems C, Holmes A, Lesch KP, Murphy DL (2005) Altered serotonin synthesis, turnover and dynamic regulation in multiple brain regions of mice lacking the serotonin transporter. Neuropharmacology 49:798-810.

Kuru M, Ueta Y, Serino R, Nakazato M, Yamamoto Y, Shibuya I, Yamashita H (2000) Centrally administered orexin/hypocretin activates HPA axis in rats. Neuroreport 11:1977-1980.

Lee HJ, Lee MS, Kang RH, Kim H, Kim SD, Kee BS, Kim YH, Kim YK, Kim JB, Yeon BK, Oh KS, Oh BH, Yoon JS, Lee C, Jung HY, Chee IS, Paik IH (2005a) Influence of the serotonin transporter promoter gene polymorphism on susceptibility to posttraumatic stress disorder. Depress Anxiety 21:135-139.

Lee HS, Park SH, Song WC, Waterhouse BD (2005b) Retrograde study of hypocretin-1 (orexin-A) projections to subdivisions of the dorsal raphe nucleus in the rat. Brain Res 1059:35-45.

Lee MG, Hassani OK, Jones BE (2005c) Discharge of identified orexin/ hypocretin neurons across the sleep-waking cycle. J Neurosci 25:67166720.

Léna C, Popa D, Grailhe R, Escourrou P, Changeux JP, Adrien J (2004) Beta2-containing nicotinic receptors contribute to the organization of sleep and regulate putative micro-arousals in mice. J Neurosci 24:57115718 .

Li Q, Wichems C, Heils A, Van De Kar LD, Lesch KP, Murphy DL (1999) Reduction of 5-hydroxytryptamine (5-HT)(1A)-mediated temperature and neuroendocrine responses and 5-HT(1A) binding sites in 5-HT transporter knockout mice. J Pharmacol Exp Ther 291:999-1007. 
Li Q, Wichems C, Heils A, Lesch KP, Murphy DL (2000) Reduction in the density and expression, but not G-protein coupling, of serotonin receptors (5-HT1A) in 5-HT transporter knock-out mice: gender and brain region differences. J Neurosci 20:7888-7895.

Li Y, Gao XB, Sakurai T, van den Pol AN (2002) Hypocretin/Orexin excites hypocretin neurons via a local glutamate neuron-A potential mechanism for orchestrating the hypothalamic arousal system. Neuron 36:11691181 .

Liu RJ, van den Pol AN, Aghajanian GK (2002) Hypocretins (orexins) regulate serotonin neurons in the dorsal raphe nucleus by excitatory direct and inhibitory indirect actions. J Neurosci 22:9453-9464.

Livak KJ, Schmittgen TD (2001) Analysis of relative gene expression data using real-time quantitative PCR and the 2(-Delta Delta C(T)) Method. Methods 25:402-408.

Lowry OH, Rosebrough NJ, Farr AL, Randall RJ (1951) Protein measurement with the Folin phenol reagent. J Biol Chem 193:265-275.

Lu J, Sherman D, Devor M, Saper CB (2006) A putative flip-flop switch for control of REM sleep. Nature 441:589-594.

Lutter M, Krishnan V, Russo SJ, Jung S, McClung CA, Nestler EJ (2008) Orexin signaling mediates the antidepressant-like effect of calorie restriction. J Neurosci 28:3071-3075.

Marcus JN, Aschkenasi CJ, Lee CE, Chemelli RM, Saper CB, Yanagisawa M, Elmquist JK (2001) Differential expression of orexin receptors 1 and 2 in the rat brain. J Comp Neurol 435:6-25.

Marinesco S, Bonnet C, Cespuglio R (1999) Influence of stress duration on the sleep rebound induced by immobilization in the rat: a possible role for corticosterone. Neuroscience 92:921-933.

Mathews TA, Fedele DE, Coppelli FM, Avila AM, Murphy DL, Andrews AM (2004) Gene dose-dependent alterations in extraneuronal serotonin but not dopamine in mice with reduced serotonin transporter expression. J Neurosci Methods 140:169-181.

Meerlo P, Easton A, Bergmann BM, Turek FW (2001) Restraint increases prolactin and REM sleep in C57BL/6J mice but not in BALB/cJ mice. Am J Physiol Regul Integr Comp Physiol 281:R846-854.

Mileykovskiy BY, Kiyashchenko LI, Siegel JM (2005) Behavioral correlates of activity in identified hypocretin/orexin neurons. Neuron 46:787-798.

Muraki Y, Yamanaka A, Tsujino N, Kilduff TS, Goto K, Sakurai T (2004) Serotonergic regulation of the orexin/hypocretin neurons through the 5-HT1A receptor. J Neurosci 24:7159-7166.

Murphy DL, Fox MA, Timpano KR, Moya PR, Ren-Patterson R, Andrews AM, Holmes A, Lesch KP, Wendland JR (2008) How the serotonin story is being rewritten by new gene-based discoveries principally related to SLC6A4, the serotonin transporter gene, which functions to influence all cellular serotonin systems. Neuropharmacology 55:932-960.

Pace-Schott EF, Hobson JA (2002) The neurobiology of sleep: genetics, cellular physiology and subcortical networks. Nat Rev Neurosci 3:591-605.

Peyron C, Tighe DK, van den Pol AN, de Lecea L, Heller HC, Sutcliffe JG, Kilduff TS (1998) Neurons containing hypocretin (orexin) project to multiple neuronal systems. J Neurosci 18:9996-10015.

Popa D, Léna C, Alexandre C, Adrien J (2008) Lasting syndrome of depression produced by reduction in serotonin uptake during postnatal development: evidence from sleep, stress, and behavior. J Neurosci 28:3546-3554.

Rampin C, Cespuglio R, Chastrette N, Jouvet M (1991) Immobilisation stress induces a paradoxical sleep rebound in rat. Neurosci Lett 126:113-118.

Reyes TM, Walker JR, DeCino C, Hogenesch JB, Sawchenko PE (2003) Categorically distinct acute stressors elicit dissimilar transcriptional profiles in the paraventricular nucleus of the hypothalamus. J Neurosci 23:56075616.

Roche M, Commons KG, Peoples A, Valentino RJ (2003) Circuitry underlying regulation of the serotonergic system by swim stress. J Neurosci 23:970-977.

Russell SH, Small CJ, Dakin CL, Abbott CR, Morgan DG, Ghatei MA, Bloom SR (2001) The central effects of orexin-A in the hypothalamic-pituitary- adrenal axis in vivo and in vitro in male rats. J Neuroendocrinol 13:561-566.

Sakurai T, Amemiya A, Ishii M, Matsuzaki I, Chemelli RM, Tanaka H, Williams SC, Richardson JA, Kozlowski GP, Wilson S, Arch JR, Buckingham RE, Haynes AC, Carr SA, Annan RS, McNulty DE, Liu WS, Terrett JA, Elshourbagy NA, Bergsma DJ, Yanagisawa M (1998) Orexins and orexin receptors: a family of hypothalamic neuropeptides and $G$ proteincoupled receptors that regulate feeding behavior. Cell 92:573-585.

Sakurai T, Nagata R, Yamanaka A, Kawamura H, Tsujino N, Muraki Y, Kageyama H, Kunita S, Takahashi S, Goto K, Koyama Y, Shioda S, Yanagisawa M (2005) Input of orexin/hypocretin neurons revealed by a genetically encoded tracer in mice. Neuron 46:297-308.

Salomon RM, Ripley B, Kennedy JS, Johnson B, Schmidt D, Zeitzer JM, Nishino S, Mignot E (2003) Diurnal variation of cerebrospinal fluid hypocretin-1 (Orexin-A) levels in control and depressed subjects. Biol Psychiatry 54:96-104.

Sinha RK (2006) P-CPA pretreatment reverses the changes in sleep and behavior following acute immobilization stress rats. J Physiol Sci 56:123-129.

Smith MI, Piper DC, Duxon MS, Upton N (2003) Evidence implicating a role for orexin-1 receptor modulation of paradoxical sleep in the rat. Neurosci Lett 341:256-258.

Soffin EM, Gill CH, Brough SJ, Jerman JC, Davies CH (2004) Pharmacological characterisation of the orexin receptor subtype mediating postsynaptic excitation in the rat dorsal raphe nucleus. Neuropharmacology 46:1168-1176.

Spinazzi R, Andreis PG, Rossi GP, Nussdorfer GG (2006) Orexins in the regulation of the hypothalamic-pituitary-adrenal axis. Pharmacol Rev 58:46-57.

Taheri S, Gardiner J, Hafizi S, Murphy K, Dakin C, Seal L, Small C, Ghatei M, Bloom S (2001) Orexin A immunoreactivity and preproorexin mRNA in the brain of Zucker and WKY rats. Neuroreport 12:459-464.

Takahashi K, Wang QP, Guan JL, Kayama Y, Shioda S, Koyama Y (2005) State-dependent effects of orexins on the serotonergic dorsal raphe neurons in the rat. Regul Pept 126:43-47.

Takahashi K, Lin JS, Sakai K (2008) Neuronal activity of orexin and nonorexin waking-active neurons during wake-sleep states in the mouse. Neuroscience 153:860-870.

Tao R, Ma Z, McKenna JT, Thakkar MM, Winston S, Strecker RE, McCarley RW (2006) Differential effect of orexins (hypocretins) on serotonin release in the dorsal and median raphe nuclei of freely behaving rats. Neuroscience 141:1101-1105.

Tjurmina OA, Armando I, Saavedra JM, Goldstein DS, Murphy DL (2002) Exaggerated adrenomedullary response to immobilization in mice with targeted disruption of the serotonin transporter gene. Endocrinology 143:4520-4526.

Van Reeth O, Weibel L, Spiegel K, Leproult R, Dugovic C, Maccari S (2000) Interactions between stress and sleep: from basic research to clinical situations. Sleep Med Rev 4:201-219.

Wang QP, Koyama Y, Guan JL, Takahashi K, Kayama Y, Shioda S (2005) The orexinergic synaptic innervation of serotonin- and orexin 1-receptorcontaining neurons in the dorsal raphe nucleus. Regul Pept 126:35-42.

Wellman CL, Izquierdo A, Garrett JE, Martin KP, Carroll J, Millstein R, Lesch KP, Murphy DL, Holmes A (2007) Impaired stress-coping and fear extinction and abnormal corticolimbic morphology in serotonin transporter knock-out mice. J Neurosci 27:684-691.

Winsky-Sommerer R, Yamanaka A, Diano S, Borok E, Roberts AJ, Sakurai T, Kilduff TS, Horvath TL, de Lecea L (2004) Interaction between the corticotropin-releasing factor system and hypocretins (orexins): a novel circuit mediating stress response. J Neurosci 24:11439-11448.

Wisor JP, Wurts SW, Hall FS, Lesch KP, Murphy DL, Uhl GR, Edgar DM (2003) Altered rapid eye movement sleep timing in serotonin transporter knockout mice. Neuroreport 14:233-238.

Yoshida K, McCormack S, España RA, Crocker A, Scammell TE (2006) Afferents to the orexin neurons of the rat brain. J Comp Neurol 494:845-861. 